\title{
MORE THAN SEALS AND SEA OTTERS: OPA CAUSATION AND MORATORIUM DAMAGES
}

\author{
ALLAN KANNER*
}

\begin{abstract}
Following the 2010 BP/Deepwater Horizon oil spill, the Federal Government issued a drilling and permitting moratorium in the Gulf of Mexico that resulted in significant economic losses for many businesses that serve the oil and gas industry. The Oil Pollution Act should have covered these economic damages; however, the Eastern District of Louisiana held otherwise. This article details how the Oil Pollution Act should have been applied to those who suffered economic loss as a result of the oil spill following the six month moratorium in the Gulf.
\end{abstract}

\section{INTRODUCTION}

On April 20, 2010, the Deepwater Horizon mobile offshore drilling unit suffered from a catastrophic blowout, explosion, and subsequent fire, which killed 11 people and injured at least 17 in the Gulf of Mexico. ${ }^{1}$ Two days later, on April 22, the Deepwater Horizon capsized and sank, collapsing the marine riser (a pipe connecting the drilling unit to the well), which then fractured. ${ }^{2}$ By the time the well was capped on July 15, 2010, almost three months after the initial incident, nearly four million barrels of oil had escaped the damaged wellhead and 3.19 million barrels ${ }^{3}$ had reached Gulf waters. ${ }^{4}$ The incident was declared a "Spill of National Significance" under the National Contingency Plan on April 29, 2010. ${ }^{5}$ On April 30, President Obama ordered Secretary of the Interior Ken Salazar to review the blowout, fire, and sinking of the

Copyright @ 2017 Allan Kanner.

* Partner, Kanner \& Whiteley, L.L.C., New Orleans, LA; B.A., U. of Pennsylvania, 1975; J.D., Harvard Law School, 1979.

1. In re “Deepwater Horizon”, 168 F. Supp. 3d 908, 909 (E.D. La. 2016).

2. $I d$.

3. Id. at 910 (stating that 810,000 barrels were collected at the wellhead and did not enter the marine environment).

4. Id.

5. Id. (quoting Hornbeck Offshore Servs. v. Salazar, 713 F.3d 787, 789 (5th Cir. 2013)). 
Deepwater Horizon and to report "what, if any, additional precautions and technologies should be required to improve the safety of oil and gas exploration and production operations on the outer continental shelf." ${ }^{\prime 6}$ Secretary Salazar issued his findings on May 6, 2010, stating, "as a result of the Deepwater Horizon explosion and spill . . . no applications for drilling permits [would] go forward for any new offshore drilling activity." "The Secretary's report ultimately recommended a six month moratorium on all drilling activity, either present or pending, in the Gulf of Mexico. ${ }^{8}$

In its simplest form, a moratorium is "a 'suspension of activity."" For example, if a road is closed, the ramifications of such a closure could qualify as a moratorium on driving. In the case of the Deepwater Horizon, the moratorium consisted of a few phases. Immediately following the blowout, the Coast Guard and NOAA closed fishing sites ${ }^{10}$ altered and closed navigation and aviation areas, and instructed people to avoid the disaster area. ${ }^{11}$ The Coast Guard's preventative measures continued until May 2011. ${ }^{12}$ As such, each phase of the moratorium following the Deepwater Horizon disaster requires a factintensive inquiry into causation and damages. ${ }^{13}$ Two of these inquiries at issue in the $\mathrm{B} 1$ bundle $^{14}$ litigation were the moratorium and the

\section{Id.}

7. $I d$.

8. Id.

9. Moratorium, MERRIAM-WEBSTER, http://www.merriamwebster.com/dictionary/moratorium (last visited Sept. 16, 2017).

10. Deepwater Horizon/BP Oil Spill: Size and Percent Coverage of Fishing Area Closures Due to BP Oil Spill

http://sero.nmfs.noaa.gov/deepwater_horizon/size_percent_closure/index.html (last visited Nov. 10, 2017).

11. Oil and Chemical Spills, HTTPS://OCEANSERVICE.NOAA.GOV/HAZARDS/SPILLS/ (LAST VISITED NOV. 10, 2017).

12. See Plaintiffs' Memorandum in Opposition to BP's Renewed Motion to Dismiss, Addendum B at 9, In re "Deepwater Horizon", 168 F. Supp. 3d 908 (E.D. La. 2016) (No. 15704).

13. The plaintiffs, defendants, and the court agreed that this inquiry would be extremely fact intensive. In his opinion dismissing BP's motion for summary judgement on the B1 Bundle claims, Judge Barbier noted: "The parties acknowledge that these claims are fact specific and present $a$ more attenuated causation analysis than the other claims for economic loss, and they compare and contrast the instant Moratorium claims and VoO claims with the facts in the few cases that have been decided" and later "[t]he Court need not define causation under OPA-necessarily a highly factual analysis - at this stage of the pleadings. The Court is satisfied that the VoO and Moratorium Plaintiffs have alleged sufficient facts to state plausible claims in the B1 bundle." In re "Deepwater Horizon", 808 F. Supp. 2d 943, 965-66 (E.D. La. 2011) (emphasis added). Despite this agreement, the court's ruling dismissing the moratorium claims did not contain a factual analysis regarding the specifics of these claims and even stated that it would not delve into the causation argument. See generally In re "Deepwater Horizon", 168 F. Supp. 3d at 908.

14. Given the vast quantity of claims, the MDL was organized into pleading bundles based 
permitoria, which was the original halt in and subsequent slowdown of permitting by the Mineral Management Service (MMS). ${ }^{15}$ This article deals conceptually with both but for the sake of simplicity, references the case generally as the "Moratorium."

The Moratorium was the subject of multiple legal cases as affected companies attempted to recoup lost profits. ${ }^{16}$ Concerned by the lost time and profits, several companies filed suit alleging that the Moratorium violated the Administrative Procedure Act (APA) because it was arbitrary and capricious. ${ }^{17}$ Judge Feldman of the Eastern District of Louisiana agreed and issued an injunction blocking the Moratorium on June 22, 2010. ${ }^{18}$ Secretary Salazar then rescinded the original Moratorium and reissued an amended version on July 12, 2010, which included a more detailed account of his reasoning. ${ }^{19}$ On September 29, 2010, the Fifth Circuit held that the reissued Moratorium mooted the original injunction, allowing the terms of the July Moratorium to proceed..$^{20}$ Finally, on October 12, 2010, the Moratorium was lifted. ${ }^{21}$

Despite the fact that the Moratorium was not maintained for the entire six month period, many companies-both drilling companies and those that serve them-suffered lost profits as the permitting process was halted and then delayed, sometimes up to a year, until the MMS began processing applications again. ${ }^{22}$ These companies sued as part of the BP/Deepwater Horizon Multidistrict Litigation (MDL). They were members of the B1 pleading bundle, which contained "all claims for private or non-governmental economic loss and property damages." ${ }^{23}$ On March 10, 2016, Judge Barbier of the Eastern District

on their nature. The B1 bundle dealt with non-governmental private and business loss claims, including economic losses. Case Management Order No. 1, In re "Deepwater Horizon", 168 F. Supp. 3d 908 (E.D. La. 2016), available at http://online.wsj.com/public/resources/documents/ 091410BPplaintiffsmotion.pdf (last visited Nov. 10, 2017)'.

15. Which was reorganized as of October 2011 and is now known as the Bureau of Ocean Energy Management, Regulation and Enforcement (BOEM).

16. The lead author was counsel for the State of Louisiana in the Moratorium litigation before Judge Feldman and OPA litigation before Judge Barbier. See, e.g., In the News, KANNER\&WHITELEY (June 10, 2010) https://www.kanner-law.com/kw-hired-to-representlouisiana-against-bp/.

17. Hornbeck Offshore Servs. v. Salazar, 696 F. Supp. 2d 627, 636 (E.D. La. 2010).

18. Id. at 639 .

19. In re "Deepwater Horizon", 168 F. Supp. 3d 908, 911 (E.D. La. 2016).

20. Hornbeck, 713 F.3d at 791.

21. "Deepwater Horizon," 168 F. Supp. 3d at 911.

22. Id.

23. In re "Deepwater Horizon", 808 F. Supp. 2d 943, 947 (E.D. La. 2011) (internal quotation marks omitted). 
of Louisiana held that the Moratorium losses did not fall within the scope of the Oil Pollution Act (OPA), and as such, that these companies could not recover. ${ }^{24}$ I respectfully disagree with the court and believe that such a reading is overly narrow and contrary to the purpose and design of OPA.

Though the court did not specifically address the causation standard under OPA, it did so implicitly by analyzing the wording of the statute and excluding economic damages arising from the Moratorium. ${ }^{25}$ In fact, it stated that "[t]he Court makes clear that it need not and does not decide whether or not $\S 2702(\mathrm{a})$ and/or $\S$ 2702(b)(2)(E) incorporates a proximate causation standard, etc." ${ }^{26}$ Despite that statement, the court included a two-step proximate causation standard in its analysis. OPA is a strict liability statute designed to restore property and natural resources to pre-incident baselines and to compensate public and private parties for losses that they incurred, whether they involve actual property damage or purely economic damages..$^{27}$ The sections at issue read as follows:

\section{A. $\S 2702(a)$ :}

[E]ach responsible party for a vessel or a facility from which oil is discharged, or which poses the substantial threat of a discharge of oil, into or upon the navigable waters ... is liable for the removal costs and damages specified in subsection (b) of this section that results from such incident.

\section{B. $\S 2702(b)(2)(E)$ :}

Profits and earning capacity - Damages equal to the loss of profits or impairment of earning capacity due to the injury, destruction, or loss of real property, personal property, or natural resources, which shall be recoverable by any claimant. ${ }^{28}$

As discussed herein, the court incorrectly interpreted the "result from" and "due to" language when deciding whether or not the Moratorium stemmed from the Deepwater Horizon spill. It also relied

24. The OPA issue was litigated and lost by counsel for the private parties to the MDL. At that point, the states and federal government, whose claims were proceeding as part of a separate Bundle, had settled their claims with BP and thus did not litigate this issue with respect to their claims.

25. Id. at $915-16$.

26. In re "Deepwater Horizon", 168 F. Supp. 3d at 918.

27. In re "Deepwater Horizon", 808 F. Supp. 2d at 959.

28. 33 U.S.C. $\$ 2702(a)$, (b)(2)(E) (2012). 
on a Fifth Circuit case, In re Taira Lynn Marine Ltd. No. 5, ${ }^{29}$ which, although it involved claims brought under OPA, was not a true OPA case as it did not involve an oil spill. ${ }^{30}$ If OPA is read in the manner Congress intended, Moratorium claims should be recoverable as they fall within the class of damages contemplated by $\S 2702(\mathrm{~b})(2)(\mathrm{E})$ and are consistent with Congress' broad purpose of deterring oil spills by the specter of strict liability for virtually unlimited damages.

There can be little doubt that a temporary moratorium would result from the worst oil spill in history. This point is noted in BP's own pre-accident risk assessment documents, which stated that a catastrophic disaster would jeopardize all drilling activities and likely merit legislative change. ${ }^{31}$ Regardless of BP's analysis, foreseeability is not a requirement of a strict liability statute. ${ }^{32}$ OPA, premised on the principle that the polluter pays, is designed to hold all polluters strictly liable for pollution events. ${ }^{33}$ There are three limited exceptions to this rule, ${ }^{34}$ none of which includes foreseeability, superseding cause, or the

29. In re "Deepwater Horizon", 168 F. Supp. 3d at 915-17.

30. Id. at 917.

31. In BP's 2009 Major Hazard Risks Placed on Risk Register report, it recognizes consequences of various levels of disasters that include health and safety, environmental impacts, and reputational impacts, which include effects to international, national, and regional legislation. Suttles Deposition at 361, In re "Deepwater Horizon", 168 F. Supp. 3d 908 (E.D. La. 2016) (No. 51911). So even if BP's "superseding cause" arguments were acceptable under OPA, it still recognizes that the type of legislative change that the Moratorium catalyzed is a direct result of its own actions. Plaintiff's Memorandum in Opposition to BP's Renewed Motion to Dismiss, "Deepwater Horizon”, 168 F. Supp. 3d 908 (E.D. La. 2016) (No. 15704-06).

32. See Kenneth M. Murchison, Liability Under the Oil Pollution Act: Current Law and Needed Revisions, 71 LA. L. REV. 917, 930 (2011) (stating that under the strict liability imposed by OPA defendants can assert only a few narrow defenses, which do not include lack of foreseeability).

33. The Organisation for Economic Co-Operative Development (OECD) defines the "Polluter Pays Principle." It states that "[t]he principle to be used for allocating costs of pollution prevention and control measures to encourage rational use of scarce environmental resources and to avoid distortions in international trade and investment is the so-called 'Polluter-Pays Principle.' This principle means that the polluter should bear the expenses of carrying out the above-mentioned measures decided by public authorities to ensure that the environment is in an acceptable state. In other words, the cost of these measures should be reflected in the cost of goods and services that cause pollution in production and/or consumption. Such measures should not be accompanied by subsidies that would create significant distortions in international trade and investment." John Remy Nash, Too Much Market? Conflict Between Tradable Pollution Allowances and the "Polluter Pays Principle," 24 HARV. ENVTL. L. REV. 465, $468-70$ (2000) (quoting OECD, Environment and Economics: Guiding Principles Concerning International Economic Aspects of Environmental Policies, May 26, 1972, annex para. 1, Doc. No. $\mathrm{C}(72) 128,1972 \mathrm{WL} 24710)$. OPA has adopted this through its strict liability regime designed to make the responsible party rather than the public pay to clean up oil spills and reimburse costs of the government and private parties that were harmed by the spill.

34. 33 U.S.C. $\$ 2703$ (a) (2012). These exceptions include an act of god, an act of war, or an 
assignment of partial blame to another party (the three exceptions set forth by BP). ${ }^{35}$ OPA's construction as a strict liability statute, its polluter pays policy, and limited liability exceptions all indicate that its causation standard is as unique as the oil spills that it is designed to address.

The causation standard has been a point of contention among courts interpreting OPA since its adoption in 1990. Because OPA does not use traditional common law terms in its liability provisions, courts have had difficulty interpreting the phrases "result from" and "due to" without applying traditional maritime and common law structures. ${ }^{36}$ Despite the desire to conform to traditional notions of tort law, it is important to read statutes in a manner consistent with Congressional intent. Generally, there is disagreement regarding whether or not Congress intended a proximate causation standard for evaluating OPA damage claims. ${ }^{37}$ While the proximate causation standard is used in OPA, it is contained in the section dedicated to limiting liability. ${ }^{38}$ Section 2704(c)(1) states that limited liability can be excluded if it can be shown that "the incident was proximately caused by" gross negligence or willful misconduct on the part of the responsible party. ${ }^{39}$ Legal canon holds that "[w]here Congress includes particular language in one section of a statute but omits it in another section of the same Act, it is generally presumed that Congress acts intentionally and purposely in the disparate inclusion or exclusion." ${ }^{40}$ Thus, it follows that the liability provisions of OPA do not include a proximate cause standard. Using the Moratorium claims as an example, this article aims to parse the meaning of the phrases "result from" and "due to" in order to show that, although OPA's causation standard likely lies somewhere between proximate cause and but-for causation, a but-for standard more closely aligns with OPA's purpose.

act or omission of a third party. The act of a third party does not include intervening or superseding causes.

35. Motion Requesting Discovery and Trial Setting on Certain of the State of Louisiana's 2010 Economic Loss Claims Under OPA, In re "Deepwater Horizon, 168 F. Supp. 3d 908 (E.D. La. 2016) (No. 7744) (highlighting four of BP's affirmative defenses noting superseding and intervening causes and proximate causation and therefore foreseeability arguments).

36. Jillian Talley, Issues Arising Under the Oil Pollution Act of 1990: The Causation Conundrum, 14 LOY. MARYMOUNT L.J. 148, 150 (2014).

37. Id.

38. 33 U.S.C. $\$ 2704(c)(1)(2012)$.

39. Id.

40. Russello v. United States, 464 U.S. 16, 23 (1983). 


\section{STATUTORY INTENT}

To understand OPA, it is necessary to examine what it replaced. Traditionally, oil spills, collisions between ships, collisions between ships and stationary objects, and any other incident arising on the navigable waters of the United States are considered cases of Admiralty belonging under the jurisdiction of federal maritime law. Until 1990, following the massive Exxon Valdez spill, marine oil pollution defendants found relief in federal maritime law. Two provisions in particular favor tortfeasors: the right to limit liability "to the value of the vessel . . . if the ship owner can show that damages sought by the victims came about 'without the privity or knowledge of the [ship]owner"" 41 and damages limited to those who could show actual physical damage (meaning no purely economic losses). ${ }^{42}$ The second rule is articulated in two prominent maritime cases: Robins Dry Dock \& Repair Co. v. Flint (Robins), 275 U.S. 303 (1927), ${ }^{43}$ a Supreme Court case, and State of Louisiana ex rel. Guste v. M/V TESTBANK $($ TESTBANK $),{ }^{44}$ a Fifth Circuit case.

In Robins, third party contractors of a ship sued the Robins Dry Dock \& Repair Company for lost profits after the ship's propeller was damaged while dry-docked. ${ }^{45}$ The third party contractors argued that because their contract with the ship's owner specified that the ship be docked for repairs every six months, the contract between the ship's owner and Robins was made for the third party's benefit, and therefore it could recover its economic damages under the contract. ${ }^{46}$ The Supreme Court rejected this argument "finding that a party to a contract who commits a tort cannot be held liable in damages to an unknown third person that has an interest in the damaged property of another person." "A7 As such, the Supreme Court adopted the Robins Dry Dock rule ("Robins rule"): a bright line rule stipulating that there is no cause of action for purely economic damages without physical injury to a proprietary interest. ${ }^{48}$

41. David W. Robertson, The Oil Pollution Act's Provisions on Damages for Economic Loss, 30 Miss. C. L. REV. 157, 166 (2011) (quoting 46 U.S.C. $\$ 30505($ b) (2006)).

42. Id.

43. Robins Dry Dock \& Repair Co. v. Flint, 275 U.S. 303 (1927).

44. 752 F.2d 1019 (5th Cir. 1985).

45. Robins Dry Dock, 275 U.S. 303 at 307.

46. Id.

47. Talley, supra note 36 , at 152 .

48. Id. 
Then, in 1985, a bulk carrier and a container ship collided in the Mississippi River Gulf Outlet (MRGO), causing a chemical spill. ${ }^{49}$ As such, the MRGO had to be closed, resulting in economic losses to many claimants, including those with shipping interests and fishermen who were unable to access or utilize the MRGO for the duration of the two week closure.$^{50}$ In State of Louisiana ex rel Guste v. M/V TESTBANK, the District Court upheld the Robins rule as it applied to those with shipping interests but expanded the scope of recovery to include the fishermen that were unable to access fish. ${ }^{51}$ On appeal, the Fifth Circuit expanded the Robins rule by allowing commercial fishermen to recover purely economic damages; the court noted that Union Oil Co. v. Oppen $^{52}$-which the plaintiffs cited as abolishing the Robins ruleactually "pointed out that the fishermen's losses were foreseeable and direct consequences of the spill," which creates a limited exception to the rule. ${ }^{53}$ In fact, the Union Oil court expressly declined to "open the door to claims that may be asserted by...other[s]...whose economic or personal affairs were discommoded by the oil spill." ${ }^{54}$ As such, the TESTBANK rule merely expanded the Robins rule to include commercial fishermen. All other would-be plaintiffs would still need to prove physical damage to a proprietary interest in order to recover economic damages.

These two rules were applicable when the Exxon Valdez ran aground in Prince William Sound off the coast of Alaska on March 24, 1989. There, just as in all previous oil spill cases, Robins, $M / V$ TESTBANK, and federal maritime law limited recovery only to those who could prove physical damage and to commercial fishermen. As such, countless individuals, business, and communities could not recover for their losses. ${ }^{55}$ Congress had attempted for years to reform oil spill liability, and the Exxon Valdez spill provided the best impetus for new legislation. ${ }^{56}$ Many Congressmen lamented that "poor people in Alaska ... have lost their jobs, their livelihood, their homes, and the beautiful area in which they live." ${ }^{57}$ As such, when Congress drafted

\footnotetext{
49. $M / V$ TESTBANK, 752 F.2d at 1020.

50. Id. at $1020-21$.

51. Id. at 1021 .

52. 501 F.2d 558 (9th Cir. 1974).

53. Id. at 1026 . The court also noted "that fishermen have historically enjoyed a protected position under maritime law" Id.

54. Id. at 1023 (quoting Union Oil Co. v. Oppen, 501 F.2d 558 at 570-71 (9th Cir. 1974)).

55. Talley, supra note 36 , at 158 .

56. Robertson, supra note 41, at 158.

57. See, e.g., 135 CONG. REC. S9921 (daily ed. Aug. 3, 1989) (statement of Sen. Metzenbaum).
} 
OPA, it sought to ensure that such devastation would never happen again by removing many hurdles found in typical litigation, thereby allowing victims to receive fair compensation promptly. ${ }^{58}$ One Senate report noted, "[t]hese provisions are intended to provide compensation for a wide range of injuries and are not so narrowly focused as to prevent victims of an oil spill from receiving reasonable compensation." 59 Congress stated repeatedly that OPA would cover more victims to ensure speedy economic recovery for all those affected. ${ }^{60}$

Knowing that Congress intended OPA to extend recovery to more than those affected physically and directly by an oil spill implicates the cardinal rule of statutory interpretation: "[i]n interpreting a statute a court should always turn first to one, cardinal canon before all others. We have stated time and again that courts must presume that a legislature says in a statute what it means and means in a statute what it says there." ${ }^{\text {661 }}$

This rule should guide all interpretation of OPA's causation standard because standards restricting recovery in clear contravention of Congressional intent should not be read into the statute. ${ }^{62}$ To reiterate, OPA's liability standard reads as follows:

\section{A. $\S 2702(a)$ :}

[E]ach responsible party for a vessel or a facility from which oil is discharged, or which poses the substantial threat of a discharge of oil, into or upon the navigable waters...is liable for the removal costs and damages specified in subsection (b) of this section that results from such incident.

58. Robertson, supra note 41 , at 159.

59. S. REP. NO. 101-94, at 12 (1989), reprinted in 1990 U.S.C.C.A.N. 722, 734.

60. In a footnote, Robertson highlights several quotes from congressional reports: 135 CONG. REC. H7955 (daily ed. Nov. 1, 1989) (statement of Rep. Quillen) (stating that "full, fair, and swift compensation for everyone injured by oil spills"; stating that "residents of States will be fully compensated for all economic damages"); 136 CONG. REC. H336 (daily ed. Feb. 7, 1990) (statement of Rep. Carper) (arguing to "ensure that those people or those businesses that are damaged by these spills are fairly and adequately compensated"). Robertson, supra note 41, at 175 , n.58.

61. Conn. Nat'l Bank v. Germain, 503 U.S. 249, 253-54 (1992).

62. The risk of judicial rewriting of statutes occurs in many contexts. See generally Allan Kanner, Interpreting the Class Action Fairness Act in a Truly Fair Manner, 80 TUL. L. REV. 1645 (2006) (arguing for plain reading of the statute Congress passed). 
B. $§ 2702(b)(2)(E)$ :

Profits and earning capacity - Damages equal to the loss of profits or impairment of earning capacity due to the injury, destruction, or loss of real property, personal property, or natural resources, which shall be recoverable by any claimant. ${ }^{63}$

The emphasized phrases are those that give courts pause when determining the proper causation standard in OPA cases. None of the above falls neatly within traditional maritime or tort causation standards and, as such, there is much argument about the extent to which they adhere to traditional liability standards and how far they deviate from the same.

First, it is prudent to highlight what Congress has said regarding the "result from" and "due to" language found respectively in $\S 2702$ (a) and $\S 2702(\mathrm{~b})(2)(\mathrm{E})$ : "Subsection $(\mathrm{b})(2)(\mathrm{E})$ provides that any claimant may recover for loss of profits or impairment of earning capacity resulting from [the statutory term is "due to"] injury to property or natural resources." 64 Professor Robertson points out that this is "an authoritative indication by Congress that the Section 2702(b)(2)(E) term 'due to' has the same meaning as the Section 2702(a) term 'result from." "65 Congress' concise statement on the matter unequivocally contradicts the argument that the "due to" standard places an additional causation burden on those claiming purely economic damages. $^{66}$

63. 33 U.S.C. $§ 2702(a)-(b)(2)(E)$ (2012) (emphasis added).

64. H.R. REP. NO. 101-653, at 103 (1990).

65. Robertson, supra note 41 , at 168.

66. Following the Deepwater Horizon disaster, Kenneth Feinberg was placed at the helm of the Gulf Coast Claims Facility, the purpose of which was to settle claims for economic losses against BP. Feinberg requested that Professor John C.P. Goldberg of Harvard write a memo discussing the meaning of $\S 2702(\mathrm{~b})(2)(\mathrm{E})$ so that Feinberg will be able to discern which claims fall under the scope of OPA and which do not. Notably, Feinberg was not independent of BP and as such some believe was seeking to limit as many claims as possible. Professor Goldberg posited that this particular section added a commercial use right requirement as the "due to" added another layer of proof. The professor states that "[t]his statutory language is best understood to allow recovery only by those economic loss claimants who can prove that they have suffered economic loss because a spill has damaged, destroyed, or otherwise rendered physically unavailable to them property or resources that they have a right to put to commercial use." Id. at 164 (quoting John C. P. Goldberg, Liability for Economic Loss in Connection with the Deepwater Horizon Spill, 30 Miss. C. L. REV. 335, 337 (2010). In other words, Professor Goldberg incorrectly contends that Congress did not in fact expand recovery past what $M / V T E S T B A N K$ allowed. See generally Louisiana v. M/V TESTBANK, 752 F.2d 1019 (5th Cir. 1985)). Under such a proposition claimants would have to show that the natural resource was injured, that they suffered economic loss, and that they would have been able to put that natural resource to commercial use, such as through fishing. 
Since Congress intended the "due to" and "result from" language to be synonymous, it is important to reemphasize that "[w]here Congress includes particular language in one section of a statute but omits it in another section of the same Act, it is generally presumed that Congress acts intentionally and purposely in the disparate inclusion or exclusion." ${ }^{67}$ Many responsible parties have attempted to interpret $\S 2702(b)(2)(E)$ as somehow including a proximate cause, use right, or similarly restrictive standard. Upon a proper reading, such restrictions do not exist because the "due to" language found in section (E) is intended to mirror the "result from" language of $\S 2702(a){ }^{68}$ In order to understand these distinctions, $\S 2702$ (b) provides a list of the classes of claimants and the prerequisites for each to recover. ${ }^{69}$

Importantly, § 2702(b)(2)(C) includes a use standard that directly addresses the use of natural resource for subsistence while section (E) does not. Section 2702(b)(2)(C) directly addresses those that use natural resources for subsistence use. ${ }^{70}$ Damages are recoverable by "any claimant who so uses natural resources which have been injured, destroyed, or lost, without regard to the ownership or management of the resources." ${ }^{11}$ The mere existence of this section refutes Professor Goldberg's contention that section (E) is only intended for those who use the injured natural resource for economic gain, such as commercial fishermen. ${ }^{72}$ Further, this section requires a claimant to show that the natural resource has been damaged, whereas in section (E) the claimants' losses need only be due to (i.e. result from) the injury. ${ }^{73}$ If the proper statutory interpretation canon is applied, Congress' decision to leave such a use-right out of section (E) indicates that they intended for the section to cover more claimants than just those who subsist off natural resources. Congress would not have included (E) as superfluous language if it had meant for it to follow the same standard

67. Russello v. United States, 464 U.S. 16, 23 (1983).

68. See M/V TESTBANK, 752 F.2d 1019 note 44.

69. 33 U.S.C. $\$ 2702($ b) (2)(A)-(F) (2012).

70. 33 U.S.C. $\$ 2702(b)(2)(C)(2012)$.

71. Id.

72. Professor Goldberg concludes in his memo that proper interpretation of $\S 2702(b)(2)(E)$ holds that "if a spill were to deprive commercial fishermen of expected profits by killing fish they ordinarily would catch and sell, or by causing authorities to bar the fishermen from accessing those fish for a period of time, the fishermen would be entitled to recover. By contrast, operators of beach resorts in areas physically unaffected by a spill, but that nonetheless suffer economic loss because of a general downturn in tourism resulting from the spill, are among those who are not entitled to recovery under OPA."

73. 33 U.S.C. $\$ 2702(b)(2)(E)$. 
set forth in (C). ${ }^{74}$ While such a use-right standard should not be read into the statute, it is highly important that the words in the statute are given their proper statutory meaning and context.

Much of the responsible parties' apparent confusion comes from their failure to read $\S 2702$ (a) completely. It states that a responsible party is liable for injuries that "result from such incident." 75 It is imperative that the proper emphasis is placed on the "incident" itself, rather than on the discharge of oil. In the BP litigation, Transocean argued that "incident" in $\S 2702$ (a) is synonymous with "the discharge or threatened discharge of oil, ${ }^{, 76}$ when in fact the statute defines "incident" as "any occurrence or series of occurrences having the same origin, involving one or more vessels, facilities, or any combination thereof, resulting in the discharge or substantial threat of discharge of oil"." 77 This means that the events leading up to the discharge of oil, rather than the discharge itself, constitute the incident. For example, damages from governmental decisions to halt fishing would constitute part of the incident and not the risk of contact between the fish and oil. Liability attaches to the incident under $\S 2702$ (a), which holds that the responsible party is "liable for the removal costs and damages specified in subsection (b) of this section that result from such incident." ${ }^{\text {"78 }}$ As such, the economic damages, including the Moratorium losses that fall under $\S 2702(b)(2)(E)$, would simply have to arise from the incident. Since claimants need not show a use-right and the "due to" language is equivalent to the "result from" language, claimants under section (E) need only show that their injuries resulted from the incident that caused injury or destruction to personal property or natural resources. ${ }^{79}$

Some sections, however, do require that a certain class of claimant's injuries be caused directly by the discharge of oil. Notably, $\S 2702(\mathrm{~b})(2)(\mathrm{F})$ requires that the specified damages be "caused by a discharge of oil," which is conspicuously absent in section (E) ${ }^{80}$ It is

74. See Clark v. Rameker, 134 S. Ct. 2242, 2249 (2014) (reaffirming the rule against superfluity and holding that an interpretation of a statute that avoids superfluous language is "more faithful to the statute Congress wrote").

75. 33 U.S.C. $\$ 2702$ (a) (emphasis added).

76. Transocean's Rule 12(b)(6) Motion to Dismiss the State of Louisiana's First Amended Complaint at 32, In re "Deepwater Horizon", 168 F.Supp.3d 908 (E.D. La. 2016) (No. 2656-1).

77. 33 U.S.C. $\$ 2701(14)$ (2012).

78. 33 U.S.C. $\$ 2702$ (a) (emphasis added).

79. 33 U.S.C. at $\$ 2702(b)(2)(B)$. Importantly, plaintiffs do not need to own the injured property or natural resources as those claims are covered in $\S 2702(\mathrm{~b})(2)(\mathrm{B})$.

80. 33 U.S.C. at $\$ 2702($ b) $(2)(F)$. 
logical for section $(\mathrm{F})$ to contain such a requirement because it pertains to increased public services to protect the public from safety hazards (i.e. an oil spill). ${ }^{81}$ Once again, Congress would have included "caused by" language if it wished to limit economic damages to those directly impacted by the discharge of oil rather than the incident. "Caused by" language often has a proximate causation connotation, which, once again, is not included in $\S 2702(\mathrm{~b})(2)(\mathrm{E})$.

As noted previously, Congress did in fact include proximate cause language in other parts of the statute. For example, $\S 2704$ details the limits on responsible party liability. Responsible parties are generally not subject to unlimited liability unless it is shown that the incident was caused by gross negligence or willful misconduct. ${ }^{82}$ Importantly, the standard for proving such gross negligence or willful misconduct is proximate causation. ${ }^{83}$ Section 2704 (c) states: "Subsection (a) [limits on liability] of this section does not apply if the incident was proximately caused by ..." ${ }^{44}$ This is yet another example of Congress using language in one section and omitting it in another, which illustrates its intent to apply a different standard ${ }^{85}$ Further supporting the fact that it did not intend for the liability section to follow such a standard, it was included in OPA's predecessor legislation, as well as early iterations of the statute, but left out in the final adopted version.

The Outer Continental Shelf Lands Act (OCSLA) preceded OPA as a remedial statute for oil spills. ${ }^{86}$ The adoption of OPA repealed much of this legislation, including the portions containing a proximate causation standard. Title III of the OSCLA Amendments of 1978 provided for the recovery of damages that were "proximately caused

81. Id.

82. 33 U.S.C. at $\$ 2704(c)(1)(A)(2012)$.

83. See id. (stating that $\$ 2704$ (a) does not apply if the incident was proximately caused by gross negligence or willful misconduct).

84. Id.

85. Contrary to this clear intention, BP asserted that "When Federal statutes do not define a causation rule with specificity, the default rule is the familiar proximate cause standard," citing recent Supreme Court decisions interpreting the Copyright Act and OSCLA. BPXP's Memorandum in Opposition to the OPA Test Case Plaintiffs' Motion to Strike Affirmative Defenses and Motion In Limine Regarding Potential Third-Party Fault at 29, In re "“"Deepwater Horizon, 168 F.Supp.3d 908 (E.D. La. 2016) (No. 13269). Because it was not the standard with which it is most familiar, it reads proximate cause into OPA under the guise of convoluted congressional intent. It stated "[i]t also bears emphasis that courts presume that Congress legislates with knowledge of the interpretive backdrop against which their laws will be construed." Essentially BP is of the opinion that despite what Congress may have to say on the matter, it clearly never intended to change the causation status based on the (notably unarticulated) assumption that it is familiar with case law.

86. 43 U.S.C. $\$ 1331(a)-(q)(2012)$. 
by the discharge of oil from an offshore facility or vessel." ${ }^{17}$ OPA replaced this provision with $2702(a) .{ }^{88}$ Because Congress intended to eliminate the proximate cause requirement, such a standard should not be read into OPA's liability provision. Furthermore, Title III of the OSCLA Amendments of 1978 contained a use-right provision that was similarly left out of OPA. ${ }^{89}$ It authorized the recovery of pollutioncaused economic damages "due to injury to, or destruction of, real or personal property or natural resources...if the claimant derives at least 25 per centum of his earnings from activities which utilize the property or natural resource. ${ }^{90}$ OPA repealed and replaced this provision with $\S 2702(b)(2)(E)$, which plainly does not contain such a use-right restriction..$^{91}$ Finally, and fatally for any argument that Congress intended for a proximate cause or use right standard to be read into OPA, the first drafts of OPA did contain such provisions, but these provisions were removed before the Act was adopted in $1990 .{ }^{92}$

Proximate cause and use rights were in the first iterations of OPA but were removed prior to its final adoption..$^{93}$ Early versions of the Act included both a direct causation standard as well as a proximate cause standard. ${ }^{94}$ One version sought to limit recoverable damages to those "which are proximately cause[d] by" others attempted to limit damages to those "that arise out of or directly result from" $" 96$ a spill or threat of a spill, or those "that arise out of or directly result from such discharge or threat of discharge." 97 As to the use-right, three of the preliminary bills introduced in Congress included such a limitation in their economic loss sections ${ }^{98}$ However, as the bills made their way through the legislative process, that language was deleted. ${ }^{99}$ Such inclusion and subsequent deletions are not inconsequential. The second statutory interpretation cannon

\footnotetext{
87. Pub. L. No. 99-372, § 301(15), 92 Stat. 629 (1986).

88. See Pub. L. No. 101-380, § 2004 (1990).

89. See Robertson, supra note 41, at 186 (citing Pub. L. No. 95-372, 92 Stat. 629 (1978)).

90. Id. (citing Pub. L. No. 95-372, 92 Stat. 629, § 303(a)(2)(E)-(b)(4)).

91. 33 U.S.C. $§ 2702$ (b)(2)(E) (2012).

92. Robertson, supra note 41 , at 187.

93. Id.

94. Id.

95. H.R. 3027, 101st Cong. § 102(a)(1) (1st Sess. 1989).

96. H.R. 1465, 101st Cong. § 102(a) (1st Sess. 1989).

97. H.R. 2325, 101st Cong. § 102(a) (1st Sess. 1989).

98. Id. at $\S 102(\mathrm{a})(3)(\mathrm{D})$; H.R. 1465, 101st Cong. $\S 102(\mathrm{a})(2)(\mathrm{B})(\mathrm{v})$ (1st Sess. 1989); H.R. 3027, 101st Cong. $\S 102$ (a)(2)(B) (1st Sess. 1989).
}

99. Robertson, supra note 41, at 187. 
expounded in Russello holds: "Where Congress includes limiting language in an earlier version of the bill but deletes it prior to enactment, it may be presumed that the limitation was not intended". ${ }^{100}$ As such, it is improper to read any sort of use-right, proximate causation standard, or any similarly restrictive standard into $\S$ 2702(b)(2)(E).

\section{OPA USES A NEXUS STANDARD}

Since Congress did not intend for either a use-right or proximate cause standard to be read into the "result from" and "due to" language found in OPA's liability section, it is important to clarify what was actually intended. The standard articulated in $\S 2702(b)(2)(E)$ requires only that a nexus be shown between a spill and resulting damage. ${ }^{101}$ If we are to give meaning to the statute, as the Supreme Court has recommended, by "presum[ing] that a legislature says in a statute what it means and means in a statute what it says there," ${ }^{102}$ we should look first to the basic meaning of "result from." The plain English meaning of "result" means "to proceed or arise as a consequence, effect, or conclusion" and "from" "indicate[s] the source, cause, agent or basis." 103 Stated another way, "result from" means the cause without which the event would not have occurred, i.e. "but for," which means that responsible parties are liable for damages and removal costs that would not have accrued "but for" the incident. Such an interpretation is congruent with Congress' intention to expand the classes of claimants that can recover following an oil spill. When read with this broad nexus standard, OPA clearly allows for the recovery of Moratorium damages. Case law supports such a broad interpretation, and those cases that read the statute narrowly were decided contrary to clearly expressed Congressional intent.

100. Russello v. United States, 464 U.S. 16, 23-24 (1983).

101. See 33 U.S.C. $\$ 2702$ (b)(2)(E) (2012) (stating that applicable damages are equal to the loss of profits or impairment of earning capacity due to the injury, destruction, or loss of real property, personal property, or natural resources).

102. Conn. Nat'l Bank v. Germain, 503 U.S. 249, 253-54 (1992).

103. E.g., Result, MERRIAM-WEBSTER. COM, http://www.merriam-webster.com/dictionary/ result? show $=0 \& t=1302396398$ (last visited Nov. 10, 2017) (defining result as "to proceed or arise as a consequence, effect, or conclusion"). 


\section{OPA HAS A NUMBER OF FEATURES THAT FORECLOSE A PROXIMATE CAUSATION STANDARD}

Strict joint and several liability framed with narrow defenses, set liability caps, and a polluter pays policy, indicate that Congress did not intend for the liability provisions of OPA to include a proximate causation standard. Such a structure renders proximate causation untenable in OPA's liability provisions.

Strict joint and several liability prevents a responsible party from forcing the plaintiff to apportion the damage between all responsible parties. According to E. Donald Elliot and Mary Beth Houlihan, this feature is imperative for swift delivery of compensation. They note the following:

The idea was that 'finger-pointing' among the companies involved should not delay either the clean-up or paying compensation to the injured. Thus, the term 'responsible party' is really a misnomer; a more accurate term might be the 'initially responsible party,' because a party paying claims in the first instance under OPA90 may seek to hold others ultimately responsible. ${ }^{104}$

Those found to be responsible parties may attempt to place the blame on another actor; however, the burden of proof is steep and those parties are unlikely to prevail. Stated another way, liability to victims is easily established, though a more contentious and timeconsuming contribution process may be available in appropriate cases.

First, and importantly, OPA, despite numerous cross references to the CWA in its liability provisions, ${ }^{105}$ does not include the same government negligence defense as the CWA. ${ }^{106}$ As such, responsible parties are precluded from placing any type of blame on the United States government for its possible negligence. Furthermore, $\S$ 2703(a)(3) provides for a defense to liability if the incident was caused by "an act or omission of a third party, other than an employee or agent of the responsible party or a third party whose act or omission occurs in connection with any contractual relationship with the responsible

104. E. Donald Elliot \& MARy Beth Houlihan, A Primer on the LAW OF OIL SPILls (ALI-ABA Advanced Environmental Law Conference, 2010), http://ssrn.com/abstract=2007604 (last visited Nov. 10, 2017).

105. See, e.g., 33 U.S.C. $\$ 2702$ (b) ("Covered removal costs and damages . . . all removal costs incurred by the United States, a State, or an Indian tribe under subsection (c), (d), (e), or (l) of section 1321 of this title.").

106. See 33 U.S.C. $\$ 1321$ (f) (2012) ("Except where an owner or operator can prove that a discharge was caused solely by ... (C) negligence on the part of the United States Government."). 
party." ${ }^{107}$ Such a defense may be invoked if the responsible party can show that it "exercised due care" and "took precautions against foreseeable acts or omissions." 108 The Act goes on to define a contractual relationship, and indicates joint and several liability, stating in $\S 2703(d)(6)$ : "[n]othing in this paragraph shall affect the liability under this Act of a responsible party who, by any act or omission, caused or contributed to the discharge or substantial threat of discharge of oil which is the subject of the action relating to the facility." 109

Further still, there is no reference to any failure to mitigate damages on the part of the plaintiff akin to a contributory negligence analysis. ${ }^{110}$ Should the responsible party attempt to make such an argument, it would be foreclosed per se by the strict, joint, and several liability imposed by the statute. Under OPA, once a plaintiff has established that an actor is a responsible party such an actor may be held liable for all of the damages, regardless of whether or not other parties are at fault. ${ }^{111}$ The burden of proof then shifts to the responsible party to seek contribution from other possible responsible parties or to prove the three affirmative defenses. ${ }^{112}$

Congress only provided two other defenses to liability within OPA: an act of God or an act of war. ${ }^{113}$ Both of these extreme events added to the already-limited third party defense, making it difficult for a responsible party to evade liability. If a party is responsible in any way, these defenses will not apply. ${ }^{114}$ Such narrow defenses to liability indicate that Congress intended for polluters to be held liable in all but a very few instances. The Comprehensive Environmental Response, Compensation \& Liability Act ("CERCLA") has analogous exceptions to liability. ${ }^{115}$ In New York v. Shore Realty Corp., the court noted that "[i]nterpreting section 9607(a)(1) as including a causation

107. 33 U.S.C. $\$ 2703(a)(3)(2012)$.

108. 33 U.S.C. $\$ 2703(\mathrm{a})(3)(\mathrm{A})-(\mathrm{B})$.

109. 33 U.S.C. $\$ 2703(d)(6)$.

110. E.g. RESTATEMENT (THIRD) OF TORTS: APPORTIONMENT OF LIABILITY $\S 3$, cmts. a-b, rep. notes (2017).

111. See 33 U.S.C. § 2702(a) (2012) (stating that "each responsible party for a vessel or a facility from which oil is discharged, or which poses the substantial threat of a discharge of oil, into or upon the navigable waters or adjoining shorelines or the exclusive economic zone is liable") (emphasis added).

112. 33 U.S.C. $\$ 2709$ (2012).

113. 33 U.S.C. $\$ 2703(a)(1)-(2)$.

114. 33 U.S.C. $\$ 2703(a)$.

115. 42 U.S.C. $\$ 9707$ (b) (2012). 
requirement makes superfluous the affirmative defenses provided in section 9607(b), each of which carves out from liability an exception based on causation." 116 Importantly, unlike CERCLA, "OPA exonerates the responsible party from liability imposed by [\$2702] if that party proves by a preponderance of the evidence that the incident resulted solely from (1) an act of God; (2) an act of war; (3) an act or omission of a third party"... ."117 The addition of "solely" renders OPA's exceptions even more restrictive than CERCLA. It follows then that the interpretation and construction of such exceptions are equal to or greater than those of CERCLA. Given these narrow causational exceptions, a proximate cause standard simply does not make sense in OPA section 2702(a). Because the proximate cause standard does not make sense within the context of OPA's liability provisions, it would follow that any arguments and defenses that traditionally fall within such a causational analysis also fail to comport with OPA.

One such analysis is that of intervening and superseding causes. Under traditional tort theory, if a potential tortfeasor can show that there is an intervening and superseding cause between the time of his action and the injury of the plaintiff, he will escape liability. ${ }^{118}$ This includes a foreseeability analysis that is conspicuously absent from OPA's liability provisions. However, because OPA lists three very limited instances in which a responsible party may assert a complete defense, such arguments are inapplicable. The fact that proximate cause is included in other areas, but not in the liability section, ${ }^{119}$ means that the statute is based on strict joint and several liability. As such, even if the responsible party could point to some intervening fault of another actor, it would not absolve it of legal liability. If anything, the responsible party would be forced to seek contribution from the intervening actor. ${ }^{120}$ Finally, OPA did not include the governmental negligence exception found in the CWA. ${ }^{121}$ As such, under OPA, government actions, legal or not, ${ }^{122}$ cannot be used as a liability shield.

116. N.Y. v. Shore Realty Corp., 759 F.2d 1032, 1044 (2d Cir. 1985).

117. Russell V. RANDle, OIL POLlution DESKBoOK, 2D (2012).

118. 65 C.J.S. Negligence $\S 227$ (2017).

119. Compare 33 U.S.C. $\$ 2704$ (c)(1) (2012) (stating that subsection (a) does not apply if the incident was proximately caused by gross negligence or willful misconduct), with 33 U.S.C. $\S$ 2702(a), (b) (2012) (excluding proximate causation).

120. 33 U.S.C. $\S 2709$ (2012).

121. 33 U.S.C. $\$ 1321(f)(1)(C)$ (2012).

122. In the Moratorium case, the plaintiffs noted that BP attempted "to claim that the Moratoria, or permitting changes, or other Governmental action was 'unforeseeable' or 'unreasonable' or even 'illegal', thereby breaking the chain of causation as a 'superseding cause 
Arguably, the most important feature of OPA is its polluter pays policy. This policy is the driver behind strict, joint, and several liability and the limited defenses available to responsible parties. ${ }^{123}$ The "polluter pays" principle is based on the simple idea that the polluter, not the public, should internalize the cost of its damage to the environment. ${ }^{124}$ In European countries, this policy is implemented through proactive taxes on emissions, maintains the permitting systems, and responds to environmental disasters. ${ }^{125}$ In the United States, the polluter pays principle is found in CERCLA, ${ }^{126}$ the CWA, ${ }^{127}$ and $\mathrm{OPA}^{128}$ and forces the polluter to pay for removal and restoration costs in the event of a spill. It is evident in CWA's criminal penalties where "'It doesn't require much' to prove a criminal offense after an oil spill. 'It's basically: did BP intend to drill an oil well in the Gulf that resulted in a discharge of oil into waters of the United States?"'129 OPA's strict, joint, and several liability provides the same backstop: the responsible party is held liable for the pollution unless it can satisfy any of the three narrow exceptions. ${ }^{130}$ Congress recognized how financially debilitating strict liability can be and included a limit to liability in $\S$ $2704 .{ }^{131}$ Taken together, it is clear that Congress intended for the polluter to pay. Such intention manifested itself in the language, liability structures, and defenses it selected.

of Plaintiffs' loss." Class Counsel's Reply Brief in Further Support of Motion to Strike Affirmative Defenses and Motion In Limine Regarding Potential Third-Party Fault and Superseding Cause Defense, In re "Deepwater Horizon", 168 F. Supp. 3d 908 (E.D. La. 2016) (No. 13302).

123. Id.

124. See Nash, supra note 33 .

125. See, e.g., Coralie Noel, Capacity Building for Better Water Management, INT'L OFFICE FOR WATER 11-12 (2009), http://www.oieau.org/IMG/pdf/IOWaterWaterManagementFrance.pdf.

126. 42 U.S.C. $\$ 9707$ (2012).

127. 33 U.S.C. $\$ 1321$ (2012).

128. 33 U.S.C. $\$ 2702$ (2012).

129. E. Donald Elliot \& Mary Beth Houlihan, A Primer on the Law OF Oil Spills (ALI-ABA Advanced Environmental Law Conference, 2010), http://ssrn.com/abstract=2007604 (last visited Nov. 10, 2017).

130. Robert Force, Martin Davies \& Joshua S. Force, Deepwater Horizon: Removal Costs, Civil Damages, Crimes, Civil Penalties, and State Remedies in Oil Spill Cases, 85 Tul. L. REV. 889, 891 (2011).

131. Id. 


\section{CASE LAW SUPPORTS A BROAD INTERPRETATION OF OPA'S LIABILITY PROVISION}

There are several cases in which courts have read OPA's liability provision broadly, as was intended by Congress. The other cases that failed to read the provisions broadly were wrongly decided because they ignored clear congressional intent. Furthermore, when compared with those that do read the statute broadly, the courts almost contradict one another. Both U.S. v. Conoco, Inc. ${ }^{132}$ and U.S. v. Hyundai Merchant Marine Co., $L t d{ }^{133}$ dealt with the recovery of Coast Guard monitoring costs and allowed for recovery despite the Coast Guard's minimal involvement. By contrast, the court in Gatlin Oil Co. Inc. v. U.S. ${ }^{134}$ adopted the Coast Guard's narrow interpretation of the liability provisions, blocking Gatlin's recovery from the Federal Oil Spill Liability Trust Fund ("Fund") and, perhaps, created a loophole for would-be responsible parties. The statute cannot be read both broadly to favor the government and narrowly in response to a responsible party's valid request for reimbursement.

In U.S. v. Conoco, Inc., the Eastern District of Louisiana found that Conoco was liable for the monitoring costs incurred by the United States Coast Guard following two pipeline breaks and subsequent spills into the Gulf of Mexico. ${ }^{135}$ Although Conoco successfully removed all of the spilled oil, the Coast Guard undertook various monitoring activities to ensure intervention was not necessary. ${ }^{136}$ Such activities included helicopter flyovers, oversight of Conoco's response efforts, and an investigation into the circumstances surrounding the incidents. ${ }^{137}$ The Coast Guard argued, and the court agreed as follows:

"The government is authorized to monitor the cleanup efforts of the responsible party and OPA defines removal as including not only the actual containment or removal of oil but also such other actions as are necessary to minimize or mitigate damage to the public health or welfare." 138

The government contended that Coast Guard monitoring was necessary in order to ensure that Conoco's actions were sufficient to

132. 916 F. Supp. 581 (E.D. La. 1996).

133. 172 F.3d 1187 (9th Cir. 1999), cert. denied, 120 S. Ct. 397 (1999).

134. 169 F.3d 207 (4th Cir. 1999).

135. Conoco, 916 F. Supp. at 581.

136. Id. at 582 .

137. Id.

138. Id. at 583 . 
contain the spill, thereby minimizing and mitigating further damage. ${ }^{139}$ Conoco, however, argued that reading monitoring activities into the definition of removal is beyond the scope of the definition and that had Congress intended such a meaning, it would have drafted the definition to read, "the taking of any other action as may be necessary to ensure minimization or mitigation of damages." ${ }^{140}$ Instead, the definition as written only allows for recovery of those costs associated with the actual containment or removal of oil. ${ }^{141}$ The court disagreed. Judge Sear stated, "I view Conoco's construction of $\S 2701(30)$ as too strained. Although the statute is not a model of clarity, the language is broad enough to comport with the government's interpretation." 142

Conoco further alleged that the government's authorization to monitor cleanup activities, does not mean that the private party should be charged for the costs of such monitoring. ${ }^{143}$ Conoco read $\S 1321$ (of the Clean Water Act as referenced in OPA \$2702(b)(1)(A)) as only covering actual removal efforts. ${ }^{144}$ Once again, Judge Sear disagreed stating, "[t]his argument cannot withstand scrutiny of the OPA provisions as a whole, however, inasmuch as I accept the interpretation of 'removal' as encompassing actions beyond actual containment and cleanup." "145 Importantly, Judge Sear emphasized the "provisions as a whole" and a broad interpretation of what "removal" encompasses. From the outset, Judge Sear framed his interpretation broadly, quoting Dole v. United Steelworkers of America: "In construing a statute, the court is 'guided not by a single sentence or member of a sentence, but [must] look to the provisions of the whole law, and to its object and policy." 146 Such a reading results in a broad interpretation that covers a wide variety of government response actions - the cost of which a responsible party will be liable for under OPA.

Three years after Conoco, in U.S. v. Hyundai Merchant Marine Co., Ltd., the Ninth Circuit similarly held that the Coast Guard was entitled to recover monitoring costs, including Coast Guard salaries. ${ }^{147}$ In 1991, the bulk carrier M/V Hyundai No. 12 ran aground in the

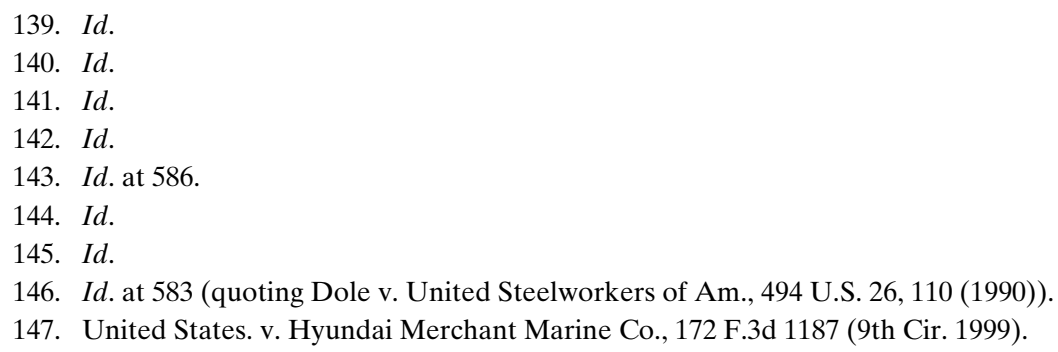


Shumagin Islands off the coast of Alaska. ${ }^{148}$ Though there was only minor spillage in the form of a 2000 -foot long sheen, the carrier had 200,000 gallons of bunker oil in its bottom fuel tanks. ${ }^{149}$ This qualified as a threatened major oil spill to which the Coast Guard responded with monitoring operations while Hyundai worked to free the ship and clean up the sheen. ${ }^{150}$ The Coast Guard stood by for eleven days while Hyundai performed the actual oil containment and ship freeing. ${ }^{151}$ The U.S. sued under OPA and the District Court awarded it $\$ 1,702,553.51 .{ }^{152}$ Hyundai appealed several aspects of that award, the crux of its argument being that a responsible party that spends millions on a successful cleanup should not have to reimburse the government for duplicative and unnecessary work. ${ }^{153}$

Like Conoco, Hyundai attempted to argue that monitoring costs do not constitute removal costs contemplated by the statute. ${ }^{154}$ Like Judge Sear, the Ninth Circuit read the relevant OPA provisions to include the removal costs enumerated in $\S 2702$ (b) as well as those cross-referenced in the CWA. ${ }^{155}$ The court highlighted the definitions of "removal costs," "removal," and "costs of removal."156 "Removal costs" are defined as "the costs of removal that are incurred after a discharge of oil has occurred or, in any case in which there is a substantial threat of a discharge of oil, the costs to prevent, minimize, or mitigate oil pollution from such incident," which clearly notes that prevention measures are covered by the statute ${ }^{157}$ Hyundai argued that the definition of "removal" prevents the government from collecting such costs because it references "actions as may be necessary," which Hyundai argued required that government actions must be necessary. ${ }^{158}$ The court, however, noted that such a reading is taken out of context. "Removal" is defined as the following:

[C]ontainment and removal of oil or a hazardous substance from water and shorelines or the taking of other actions as may be necessary to minimize or mitigate damage to the public health or welfare,

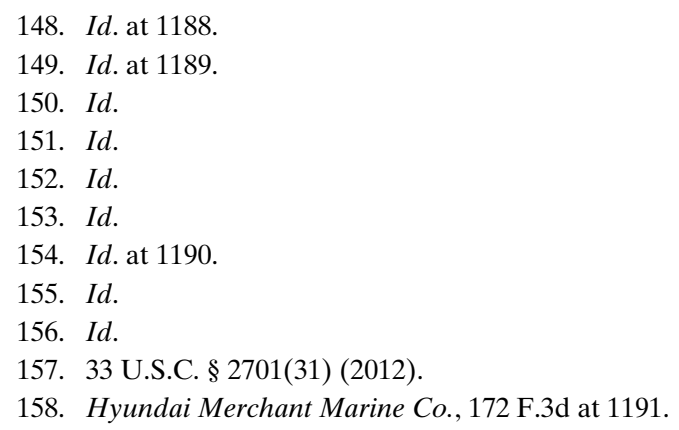


including, but not limited to, fish, shellfish, wildlife, and public and private property, shorelines, and beaches. ${ }^{159}$

The court noted, "the words 'as may be necessary' do not purport to be a limitation on reimbursement. ${ }^{160}$ They are more naturally read as an acknowledgement of executive discretion in determining the steps a particular situation requires," and, regardless, "removal costs," not "removal," was the applicable definition in this case. ${ }^{161}$

Finally, Hyundai argued that the Coast Guard's base costs, or those that it would have incurred (such as personnel salaries) whether or not it was responding to the Hyundai emergency, were not covered under OPA's liability section. ${ }^{162}$ However, the court found that the Coast Guard's base costs did in fact "result from" the incident. ${ }^{163}$ It explained that "[t]he fact that, if this near-disaster had not occurred, the personnel would have been paid to perform some other task does not alter the reality that the mishap did occur and the Coast Guard personnel were paid to monitor a potential spill." 164 The Ninth Circuit read OPA as covering all of the responses that "result from" the incident, in this case, the Hyundai No. 12 running aground. Like Conoco, the Court construed the statute broadly to cover actual response costs and those damages resulting from the underlying "incident" rather than from the oil spill.

In stark contrast with both Conoco and Hyundai's broad readings is Gatlin Oil Co. Inc. v. U.S. ${ }^{165}$ where the Fourth Circuit limited the ability of the Gatlin Oil Company to recover costs from the Fund by narrowly construing the statute. Interestingly, Gatlin is the inverse of Conoco and Hyundai, with the private responsible party seeking to recover damages and costs and the Coast Guard denying most of such recovery. On March 13, 1994, a vandal opened fuel storage tanks that were located on Gatlin's property in North Carolina, leading to the discharge of approximately 20,000-30,000 gallons of oil, some of which entered nearby drainage ditches and eventually a navigable river. ${ }^{166}$ Vapors from the released oil ignited a fire that burned for several hours, destroying much of Gatlin's property including a warehouse,

159. 33 U.S.C. $\$ 2701(30)$ (emphasis added).

160. Hyundai Merchant Marine Co., 172 F.3d at 1191.

161. Id.

162. Id. at 1192.

163. Id.

164. Id.

165. 169 F.3d 207, 214 (4th Cir. 1999).

166. Id. at 209. 
bulk plant, inventory, loading dock, several vehicles, and consuming most of the discharged fuel. ${ }^{167}$ The court held that Gatlin, the State of North Carolina, and the Coast Guard took all of the appropriate response actions. ${ }^{168}$

The Federal On-Scene Coordinator determined that 5,500 gallons of oil had reached the surrounding ditches and that 10 gallons had made their way through dikes into a nearby creek that flowed into the North Prong of the Bay River. ${ }^{169}$ Gatlin complied with all federal, and later, state clean up directives and, on July 29, 1994, the Federal OnScene Coordinator officially confirmed compliance. ${ }^{170}$ Gatlin was entitled to a complete defense given that a vandal released the oil. ${ }^{171}$ It was also entitled to recover removal costs and damages from the Oil Spill Liability Trust Fund. ${ }^{172}$ Gatlin requested $\$ 850,000$, while the Coast Guard maintained that it was only entitled to $\$ 6,959$ for the 5,500 gallons in the ditches and the 10 gallons that reached the North Prong. ${ }^{173}$ The district court agreed with Gatlin after reviewing the Coast Guard's decision under the arbitrary and capricious standard of the APA.${ }^{174}$ It remanded the case and the government appealed. ${ }^{175}$ On appeal, the Fourth Circuit ruled in favor of the Coast Guard, limiting Gatlin's recovery to the cleanup costs for the oil that had reached the ditches and navigable water. ${ }^{176}$ This holding is entirely too narrow and contrary to the proper reading and intent of the statute.

One commenter noted that such a reading of the statute is, on the surface, "consistent with one of the stated purposes of OPA: increasing the financial responsibility of a polluting party." however, Gatlin was a victim as much as the environment and did everything in its power to correct the situation while experiencing significant loss itself. The court in Gatlin wrongly focused on a single word found within $\S 2702(a)$ : "such." ${ }^{178}$ By referring to the discharge of

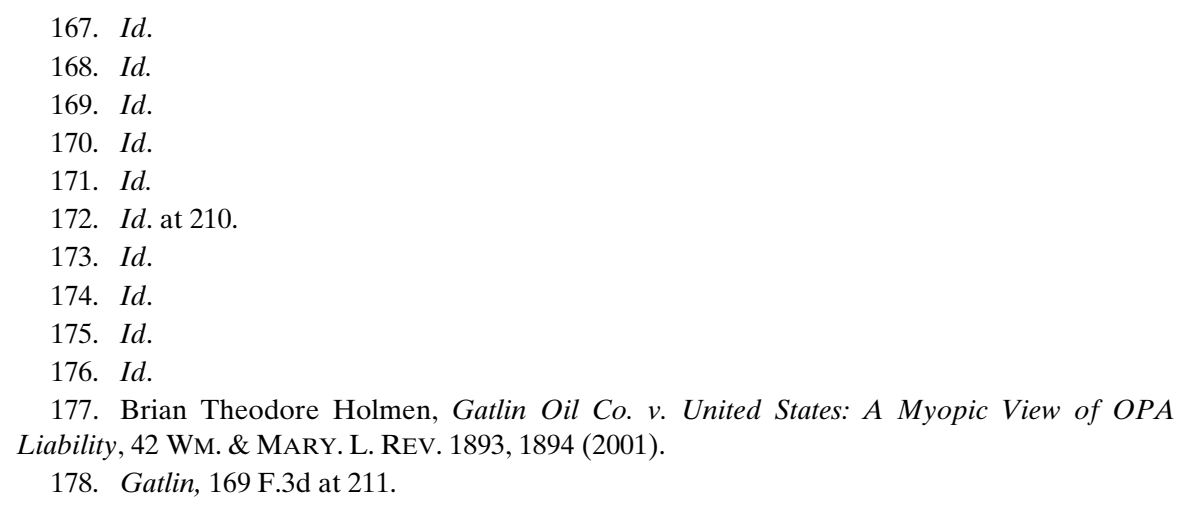


oil, which is the antecedent of "such incident," the Coast Guard interpreted the "results from such incident" language as meaning only that damages resulting from the discharge or threat of discharge of oil into navigable waters are covered. ${ }^{179}$ By parsing the language in this way, the Coast Guard interpreted "incident" to mean the actual discharge or threat of discharge of oil, rather than the actual statutory definition that encompasses "any occurrence or series of occurrences." As As such, Gatlin could not recover damages for the fire. ${ }^{181}$ The court reasoned that the fire did not cause the discharge or threat of discharge of oil, and therefore, such damages did not fall within the Coast Guard's interpretation. ${ }^{182}$

This narrow parsing directly contradicts the court in Conoco, which emphasized the statutory cannon articulated in Dole. ${ }^{183}$ It further contradicts the holdings in both Conoco and Hyundai, which read the definitions of "incident," "removal," "removal costs," and "result from," broadly in order to allow recovery for the Coast Guard, while here the Coast Guard reads the same provisions as narrowly as possible to deny recovery for Gatlin. Judge Niemeyer's dissent in Gatlin further emphasized a broad interpretation of the statutory definitions, highlighting the fact that Gatlin's fire "damages 'resulted from' the vandals' discharge of oil, a discharge which both polluted navigable waters and immediately threatened to pollute navigable waters." 184 More dangerous still is the possibility of future responsible parties limiting their own liability based on this narrow parsing of "such" and its antecedent. ${ }^{185}$ If this decision were to control, responsible parties could argue that, under Gatlin, they are only responsible for the damages caused by the actual oil reaching navigable waters and nothing else. It would likely even limit the ability of the Coast Guard itself to recover monitoring costs as it had in Conoco and Hyundai, since personnel salaries do not cause the discharge or

179. $I d$.

180. 33 U.S.C. $\$ 2701(14)$ (2012).

181. It is important to note that Gatlin's definition of incident is nonsensical as it contemplates the effect, i.e. the discharge of oil, before the cause, i.e. the vandals opening the drums. In traditional language structure, the effect cannot come before the cause. OPA's definition of "incident" is far clearer than the age old, which came first, the chicken or the egg debate. However, this is precisely the question the court in Gatlin poses, and incorrectly answers. Further still, the facts clearly indicate that the fire was a result of the vapors released by the oil, and as such, the fire is really the only damage caused by the discharge of oil. Gatlin, 169 F.3d at 209.

182. Id. at 212.

183. See Holmen supra note 177.

184. Gatlin, 169 F.3d at 214-15.

185. Holmen, supra note 177, at 1909. 
substantial discharge of oil. ${ }^{186}$ This clearly contravenes the intent of Congress in enacting OPA and even creates a window of liability narrower than that found in the impetus for OPA, the Exxon Valdez spill.

\section{SHUTDOWN CASES}

There are several cases when the shutdown of bodies of water caused economic loss that the courts agreed to hear or grant damages. In such cases, authorities (generally the Coast Guard) shut down a waterway after a spill in order to respond to, contain, and cleanup the oil. ${ }^{187}$ Those individuals and businesses that are unable to access the water, either as a route to other locations or for economic purposes, have been allowed to bring economic loss claims under $\S$ 2702(b)(2)(E). ${ }^{188}$ In the dismissal of the BP Moratorium claims, Judge Barbier held that the Moratorium was distinguishable from these cases. ${ }^{189}$ This holding, however, reads OPA's liability provision too narrowly. The Moratorium claims are very similar to claims resulting from closure of a river or a bayou and, as such, should be permitted.

In In re Settoon Towing, $L L C$, the Eastern District of Louisiana allowed claims for economic loss due to the inability to reach a production platform and the mere prospect of litigation arising from the closure of the Gulf Intracoastal Waterway. ${ }^{190}$ The conflict at issue occurred on January 20, 2007, when the M/V CATHY M. SETTOON was pushing a large barge and struck a well owned and operated by ExPert Oil \& Gas, LLC in Bayou Perot. ${ }^{191}$ Barataria Production Services (BPS), a production company, issued a written demand on ExPert for damages because it was unable to access its production platform during the cleanup process. ${ }^{192}$ ExPert, in turn, sought damages from the responsible party, Settoon Towing. ${ }^{193}$ Settoon argued that under Robins, ExPert could not allege economic damages for a third party without evidence of physical injury to a proprietary interest. ${ }^{194}$ The court disagreed, noting that "OPA legislative history makes it

186. Holmen, supra note 177 , at 1919.

187. See, e.g., In re Settoon Towing, LLC, No. 07-CV-1263, 2009 WL 4730969, at*1 (E.D. La. Dec. 4, 2009) (arising from the closure of the Gulf Intracoastal Waterway).

188. See, e.g., id. (considering a claim for economic loss).

189. In re "Deepwater Horizon", 808 F. Supp. 2d 943, 968 (E.D. La. 2011).

190. Settoon Towing, 2009 WL 4730969 , at *4.

191. Id. at $* 1$.

192. Id. at $* 2$.

193. Id.

194. Id. 
clear that to recover damages under section 2702(b)(2)(E), 'the claimant need not be the owner of the damaged property or resources to recover for lost profits or income." ${ }^{195}$ As such, the court ruled that ExPert may assert such claims against Settoon and denied Settoon's Motion for Summary Judgement. ${ }^{196}$

The court then discussed ExPert's claim for damages for "potential suits seeking economic damages for the shutdown of the Gulf Intracoastal Waterway." 197 Despite the fact that no such suits had been brought, the court held that ExPert could maintain such claims. ${ }^{198}$ It stated that " $[\mathrm{t}]$ he potential suits described by ExPert are similar to the claim made against it by BPS, i.e. claims by other businesses who suffered economic losses because they could not conduct business due to the ICW shutdown." 199 In other words, the court recognized the possibility that a shutdown of a waterway could affect many businesses, and that it is contrary to OPA to limit such claims. Interestingly, the court relied on the erroneous definitions provided by Gatlin Oil, specifically that "the claimant must show that the damage resulted from a discharge or threatened discharge of oil into navigable waters or the adjacent shoreline." 200 OPA is clearly intended to cover damages that result from the incident, not the discharge of oil itself. Despite this fact, shutdown cases still fall within what the court holds as the purview of OPA's liability provisions.

The Western District of Louisiana has similarly held that OPA's liability provisions cover economic damages resulting from waterway shutdowns. In Dunham-Price Group, LLC, et al. v. Citgo Petroleum Corp., the court denied Citgo's motion for summary judgment barring economic damages claims resulting from the closure of 22 miles of the Calcasieu River following a spill from its Lake Charles refinery. ${ }^{201}$ Dunham Price owns and operates a concrete facility several miles upriver from Citgo's refinery and the zone closed by the Coast Guard. ${ }^{202}$ It alleged that it sustained damages from loss of use, increased expenses, and business interruption resulting from the

195. Id. at *4 (citing Taira Lynn Marine Ltd. v. Jays Seafood, Inc., 444 F.3d 371, 382-83 (5th Cir. 2006) (quoting Ballard Shipping Co. v. Beach Shellfish, 32 F.3d 623, 631 (1st Cir. 1994))).

196. Id.

197. Id.

198. Id.

199. Id.

200. Id. (quoting Gatlin Oil Co. v. United States, 169 F.3d 207, 212 (4th Cir. 1999)).

201. Dunham-Price Grp., LLC v. Citgo Petroleum Corp., No. 2:07-CV-1019, 2010 WL 1285446, at *1 (W.D. La. Mar. 31, 2010).

202. Id. 
closure. ${ }^{203}$ In its ruling, the court cited the same Taira Lynn rule, also cited in Settoon, that the claimant need not own the damaged property or resources to recover economic losses. ${ }^{204}$ The court simply noted that the Calcasieu River meets OPA's definition of a natural resource and that Citgo admitted to negligently discharging 30,000 gallons of oil. ${ }^{205}$ For this reason, the court held that Dunham had presented enough evidence for a trier of fact to decide whether the economic damages were a result of the incident. ${ }^{206}$

Finally, in a recent case, the Eastern District of Louisiana once again held that economic damages due to shutdowns are appropriate under OPA. ${ }^{207}$ On July 23, 2008, the M/V TINTOMARA, an oceangoing tanker, collided with a barge, owned by American Commercial Lines, LLC (ACL), carrying thousands of barrels of oil, resulting in an oil spill in the Mississippi River near New Orleans, Louisiana. ${ }^{208}$ The Coast Guard closed 29 miles of the Lower Mississippi River following the spill, reopening it to traffic seven days later on July 30, 2008. ${ }^{209}$ The court rejected ACL's assertion that the U.S. could not recover payments made out of the Fund "to a claimant that failed to establish that the loss was caused by the oil spill," particularly those "incurred solely as a result of the Coast Guard's closing of the Mississippi River." ${ }^{210}$ The court rejected this contention, noting that:

The courts in this circuit have refused to make oiling of physical property a prerequisite for recovery of damages under the OPA; instead, they have found triable issues of fact as to causation when claimants seek damages for loss of business resulting from the closure or loss of use of a natural resource such as a river. ${ }^{211}$

ACL relied on Taira Lynn and the Moratorium case at issue in this article as supporting its position that such economic damages are not recoverable under OPA. ${ }^{212}$ Taira Lynn, quoted above, is irrelevant, ${ }^{213}$ and Deepwater Horizon was wrongly decided. In any

203. Id.

204. Id. at $* 2$.

205. Id. at $* 2-3$.

206. Id. at $* 3$.

207. United States v. Am. Commercial Lines, LLC, No. 11-CV-2076, 2016 WL 4987208, at*1 (E.D. La. Sept. 19, 2016).

208. Id.

209. Id.

210. Id. at $* 5$.

211. Id.

212. $I d$.

213. Id. 
event, the court in $A C L$ held that neither case adequately supported ACL's position. ${ }^{214}$

It is important to highlight the court's language in describing the natural resource damages. That language, unlike the language in all of the above cases, does not cite Gatlin's incorrect position that there must be damage from the oil; rather, it states that economic loss claims may "result[] from the closure or loss of use of a natural resource such as a river." 215 This points to the incident rather than the direct oiling as suggested in Gatlin. The Moratorium, in essence a very large shutdown, was the direct result of the incident.

\section{THE OIL-LESS OPA CASE}

Throughout the Moratorium claims arguments and subsequent decisions both Transocean and Judge Barbier highlight and referenced a Fifth Circuit case as pertaining to OPA causation. ${ }^{216}$ In fact, the cited case lacked an actual oil spill, and its limited OPA discussion relied on the wrongly decided Gatlin decision. ${ }^{217}$ In Taira Lynn Marie Ltd. No. 5, LLC v. Jays Seafood, Inc. a tug and its tow carrying "a gaseous mixture of propylene/propane" allided with a bridge in St. Mary Parish, Louisiana, releasing the gas into the surrounding area, resulting in a temporary evacuation of the businesses and residences within a designated radius of the bridge. ${ }^{218}$ The businesses that were forced to evacuate brought damages claims, including claims for purely economic losses, under general maritime law, CERCLA, OPA, and state law. ${ }^{219}$

The district court found that there was a geographical exception to the general rule that purely economic losses were not recoverable without physical damage, thereby allowing claimants with such claims a chance to pursue them in court. ${ }^{220}$ On appeal, the Fifth Circuit barred recovery based on the $M / V T E S T B A N K$ rule, noting that there is no such geographical exception. ${ }^{221}$ Further, although it addressed OPA, the court seemed skeptical that the statute even applied and did not address the liability provision $\S 2702(a)$ or the "result from"

214. Id.

215. Id. (emphasis added).

216. Taira Lynn Marine Ltd. v. Jays Seafood, Inc., 444 F.3d 371, 382-83 (5th Cir. 2006).

217. Id.

218. Id. at $375-76$.

219. Id. at 376 .

220. Id. (citing In re Taira Lynn Marine Ltd., 349 F. Supp. 2d 1026, 1032 (W.D. La. 2004)).

221. Id. at 378 . 
language..$^{222}$ When deciding that claimants could not recover under OPA, the court relied on the wrongly decided Gatlin decision. ${ }^{223}$ If OPA were to apply, the court should have read the liability provision rather than the Gatlin decision, which would have analyzed the economic losses based on the incident (i.e. the allision, rather than the release of the gas). If gas is synonymous with oil, the claimants should have been able to recover under OPA, because their losses resulted from the allision, the resulting release of gas, and the evacuation.

However, it is not clear that gas is synonymous with oil, and as such, it is not likely that the claims should have even been evaluated under OPA. ${ }^{224}$ Further still, the court reluctantly addressed OPA, but relied more heavily on $M / V T E S T B A N K$ in its decision to dismiss the economic damage claims. ${ }^{225}$ As discussed extensively above, OPA replaced the $M / V T E S T B A N K$ rule in order to allow more claimants to recover from the multifaceted damage of an oil spill. ${ }^{226}$ As such, though Taira Lynn states the general proposition that OPA allows for purely economic damages, ${ }^{227}$ it is not exemplar OPA case law. The court was hesitant to hold that OPA was applicable and when it did, refrained from discussing both causation and liability. However, OPA is unquestionably applicable in the Moratorium case. When dismissing the Moratorium claims, Judge Barbier relied almost entirely on the Taira Lynn decision even though he recognized that "Taira Lynn does not align perfectly with the cases at hand because the gaseous discharge caused no direct damage to property or resources (whether owned by

222. Id. at 383. The court posits: "Even assuming arguendo that OPA applies, none of the claimants has raised an issue of fact as to whether any property damage was caused by the pollution incident, i.e., the release of the gaseous cargo. A party is liable under OPA if, inter alia, the claimant's damages result from such incident, i.e., the discharge or threatened discharge of oil." See 33 U.S.C. \$ 2702(a) (2012) (emphasis added); Gatlin Oil Co. v. United States, 169 F.3d 207, 210-11 (4th Cir. 1999) ("The Coast Guard has interpreted the Act to provide that only removal costs and damages that 'result from such incident' are compensable.") citing § 2702(a).

223. Taira Lynn, 444 F.3d at 382-83.

224. There is good evidence that a propane/propylene mixture contains hydrogen sulfide, which is listed as a hazardous air pollutant under the Clean Air Act (CAA). 42 U.S.C. § 7412(b)(1) (2012). OPA defines oil as "oil of any kind or in any form, including petroleum, fuel oil, sludge, oil refuse, and oil mixed with wastes other than dredged spoil but does not include any substance which is specifically listed or designated as a hazardous substance under subparagraphs (A) through (F) of section 101(14) of [CERCLA]." 33 U.S.C. § 2701(23) (2012) (emphasis added). When CERCLA is cross referenced, it provides that hazardous substance includes "any hazardous air pollutant listed under section 112 of the [CAA].” 42 U.S.C. § 9601(14)(E) (2012). It follows then that the mixture discharged in Taira Lynn is a hazardous substance covered by the CAA and CERCLA and not OPA.

225. Taira Lynn, 444 F.3d at 378-79.

226. See Robertson, supra note 41.

227. See generally In re Taira Lynn, 349 F. Supp. 2d 1026 (W.D. La. 2004). 
the plaintiffs or not), whereas the HORIZON/Macondo spill caused extensive damage to property and resources." 228 If Judge Barbier wished to rely on Taira Lynn despite its tenuous OPA claims, he would, in effect, be relying on the Gatlin decision, and if that were to apply to the HORIZON/Macondo spill, which, as he readily notes caused extensive damage, injuries resulting from such damage would be covered. Those injuries include the Moratorium claims.

\section{THE MORATORIUM CLAIMS FALL WITHIN THE DAMAGES CONTEMPLATED BY $\S 2702(\mathrm{~B})(2)(\mathrm{E})$}

On March 10, 2016, Judge Barbier of the Eastern District of Louisiana granted BP's Motion to Dismiss Moratoria/Permitoria Claims, thereby dismissing the economic damage claims brought by members of the oil industry following the Moratorium on drilling in the Gulf of Mexico. ${ }^{229}$ To reiterate, Secretary Ken Salazar announced on May 6, 2010 that "as a result of the Deepwater Horizon explosion and spill ... no applications for drilling permits [would] go forward for any new offshore drilling 'activity" ${ }^{230}$ pending his report to the president which was released on May 27 and recommended "(1) a six month moratorium on permits for new wells being drilled using floating rigs and (2) an immediate halt to drilling operations on the 33 permitted wells that [were] currently being drilled using floating rigs in the Gulf of Mexico." ${ }^{231}$ The Moratorium was challenged under the APA, resulting in a preliminary injunction forcing the Secretary to reissue a revised Moratorium, which was released on July 12, 2010.232 Despite the fact that the Moratorium was scheduled to last six months, it was lifted on October 12, 2010. ${ }^{233}$ Members of the B1 bundle sued under OPA for the economic damages they suffered as a result of the Moratorium and resultant backlog of permit evaluation at the Marine Management Service, known as the Permitoria. ${ }^{234}$ The plaintiffs in question, who make up one of the test cases for the MDL, included a marine salvage and commercial diving business; an offshore platform rig provider; a salvager of offshore production equipment; an oil and

228. In re "Deepwater Horizon", 168 F.Supp.3d 908, 917 (E.D. La. 2016).

229. Id. at 917-18.

230. Id. at 910 (quoting Hornbeck Offshore Servs. v. Salazar, 713 F.3d 787, 789 (5th Cir. 2013))

231. Id.

232. Id. at 910-11.

233. Id. at 911 .

234. Id. 
gas exploration and production company; a drilling services contractor; and a heavy material handling equipment inspection, maintenance, and service company. ${ }^{235}$

In its opinion, the court notes that BP is liable for damages under $\S 2702(b)(2)(E)$ "if, inter alia, the claimant's damages 'result from such incident,' i.e., the discharge or threatened discharge of oil,",236 which is a direct quotation from Taira Lynn. As noted above, Taira Lynn extrapolated this definition from Gatlin, which wrongly construed the definition of incident to mean only the discharge of oil. ${ }^{237}$ Both the court and Gatlin have failed to apply the proper statutory cannon to their definition of "incident." Where Congress includes language in one section, but omits it in another, it can be presumed that that omission was intentional. ${ }^{238} \S 2702(\mathrm{~b})(2)(\mathrm{F})$ specifies that its particular damages were "caused by a discharge of oil." 239 If Congress wished $\S$ 2702(b)(2)(E) to also be dependent on damage caused by the discharge of oil, it would have explicitly stated such a requirement.

Furthermore, Taira Lynn is a poor example of OPA case law, as it does not deal with the discharge or threatened discharge of oil. Rather, it deals with a gaseous mixture that the Taira Lynn court was not even sure fell within the purview of OPA. ${ }^{240}$ Strangely, the Fifth Circuit states that "because the connection between the HORIZON/Macondo incident and the Moratorium is even more attenuated than the gaseous release and mandatory evacuation in Taira Lynn...the court's conclusion here is certainly consistent with Taira Lynn." ${ }^{241}$ Again, there is no need to be consistent with a case that barely contains an OPA claim. Moreover, it is hard to see how a case involving the largest oil spill in U.S. history and the resultant closure of the Gulf, that the court readily concedes is due to the spill, is more attenuated than a last-ditch effort to classify a propane/propylene gaseous mixture as oil.

As noted previously, the court relied almost exclusively on Taira Lynn to formulate its opinion. Following its discussion of the definition of liability provided by Taira Lynn, it concludes:

235. Id. at $912-13$.

236. Id. at 914 (quoting Taira Lynn Marine Ltd. v. Jays Seafood, 444 F.3d 371, 383 (5th Cir. 2006)).

237. See supra text accompanying notes 178-80.

238. Russello v. United States, 464 U.S. 16, 23 (1983).

239. 33 U.S.C. $\$ 2702$ (b)(2)(F) (2012).

240. Taira Lynn Marine Ltd. v. Jays Seafood, 444 F.3d 371, 383 (5th Cir. 2006).

241. In re "Deepwater Horizon", 168 F. Supp. 3d 908, 917 (E.D. La. 2016). 
"Reading § 2701(a) and § 2702(b)(2)(E) together, Plaintiffs must establish that their economic losses were 'due to' the injury, destruction, or loss of property or natural resources that 'result[ed] from' the discharge or threatened discharge of oil from the HORIZON/Macondo well (i.e., the 'incident')." ${ }^{242}$

If the court's interpretation is correct, the plaintiffs would need to prove that the discharge of oil damaged property or natural resources and that such damage caused their economic loss. ${ }^{243}$ This echoes Professor Goldberg's two-step use right analysis discussed at length in his highly criticized memo commissioned by Mr. Feinberg. ${ }^{244}$ Once again, this wrongly adds a second layer of causational proof to the Plaintiff's burden while continuing to ignore the statutory definition of "incident." 245 As discussed extensively above, congressional intent proves that the "due to" language is the same as the "result from" language, and no second layer of proof was ever intended under the liability provisions. ${ }^{246}$ It is a strict liability standard. Any other interpretation is invalid because the two-step evaluation requires a proximate causation standard that certainly was not intended by Congress.

Furthermore, because the court relied on the definitions provided in Taira Lynn to reach this two-step conclusion, it is also relying on Gatlin. As noted previously, Gatlin sets dangerous precedent that highlights and favors the discharge or threatened discharge of oil over

242. $I d$. at 916 .

243. Interestingly, in the original opinion denying BP's motion to dismiss regarding the B1 claims, Judge Barbier cites CSX Transp., Inc. v. McBride, 564 U.S. 685, 701-03 (2011) when recognizing that Congress did not intend for "due to" and "resulting from" language to be a proximate causation standard. In re "“Deepwater Horizon, 808 F. Supp. 2d 943, 966 (E.D. La. 2011). He quotes the CSX court: "Congress, it is true, has written the words 'proximate cause' into a number of statutes. But when the legislative text uses less legalistic language e.g. 'caused by,' 'occasioned by,' 'in consequence of,' . . . and the legislative purpose is to loosen constraints on recovery, there is little reason for courts to hark back to stock, judge-made proximate cause, formulations." Id. (quoting CSX Transp., Inc., 564 U.S. at 702-03). In fact CSX dealt with the Federal Employers' Liability Act (FELA) and its causation standard. Notably, FELA holds railroads liable for injuries "resulting in whole or in part from [carrier] negligence," language that is strikingly similar to OPA. CSX Transp., Inc., 564 U.S. at 703. Justice Ginsburg held that FELA does not contain a proximate causation standard, but rather "a defendant railroad 'caused or contributed to' a railroad worker's injury 'if [the railroad's] negligence played a part - no matter how small - in bringing about the injury.'” $I d$. at 705. If OPA's analogous language is applied in the same manner, a responsible party would be liable for damages that "result from" the "incident," which does not include a two-step analysis, but a showing of a nexus between the incident and the damage.

244. 33 U.S.C. $\$ 2702$ (b)(2)(C) (2012).

245. 33 U.S.C. at $\$ 2702(\mathrm{~b})(2)(\mathrm{F})$.

246. See discussion supra Section III. 
the incident, i.e. occurrences that precipitated the discharge, going so far as to only compensate the company for the oil that reached navigable waters. ${ }^{247}$ Once again, future polluters could easily use this to mean that they are only responsible for those damages that arise from oil touching and damaging natural resources. Again, this directly contravenes Congress' intent to compensate those who suffer economic losses - an intention that does not require the two-step proximate cause showing championed by Gatlin, Taira Lynn, Professor Goldberg, and the In re Gulf Oil Spill court. Thus, despite the fact that the court did not explicitly address the causation issue under OPA, it still implicitly read the incorrect causation standard-proximate causation - into the liability provisions.

Such an improper reading is not surprising, given that the Fifth Circuit, as John Costonis noted, has a "self-confessed instinct for the "reflexive invocation of admiralty jurisdiction," which demands such a proximate causation standard. ${ }^{248}$ Unlike traditional maritime law, which is almost entirely judge-made, OPA provides a statutory remedy designed to work with regulations. Costonis notes "OPA's compensation and liability provisions are intricately crafted to pair with a command and control regulatory program on the one side, and a variety of civil and criminal fines and penalties on the other." ${ }^{249}$ It leaves little room for judges to construct rules and remedies to fill what they perceive as interstitial gaps in the statute. Costonis is concerned that the BI Bundle ruling, prior to, and ultimately affecting the outcome of the Moratorium claims, "aggressively carves out an independent, parallel track, coequal with OPA, for a maritime regime that addresses the same question to which OPA speaks, but in a different and pervasively incompatible manner." ${ }^{250}$ This incompatible manner is self-evident in the court's reading of the liability provisions, creating a maritime-esque, two-step proximate causation standard.

While there are certainly instances in which the court has a duty to fill gaps in Congress' lawmaking, the comprehensive nature and

247. See supra text accompanying notes 178-82.

248. John J. Costonis, The BP Bundle Ruling: Federal Statutory Displacement of General Maritime Law (Part I), 44 ENVTL. L. REP. NEWS \& ANALYSIS 10022, 10025 (2014) (citations omitted). In a two-part series, Costonis lays out the reasons why the BI Bundle ruling preserving federal maritime is incorrect and incompatible with an accurate reading of OPA. Because the BI Bundle left many of the traditional maritime law negligence tort remedies for economic and property losses intact, it allowed the court to fill perceived gaps with maritime theory rather than adhering to OPA's already comprehensive liability scheme when deciding the Moratorium claims.

249. Id. at 10030 .

250. Id. at 10026 . 
parallel issues present in OPA and maritime law discussion in the B1 Bundle and the Moratorium preclude any such gap-filling. Traditional displacement theory can only function within constitutional bounds when there exist certain gaps and windows that fall within the displacement lexicon. ${ }^{251}$ Costonis hazards that courts may use such technical lexicon terms to isolate portions of statutes to create gaps and windows for their rulings to fill. ${ }^{252}$ However, the actual purpose "is to determine Congress' intent, not to make a fetish of one or more of these labels, as BI Bundle does, by exiling OPA to a non-displacement no-man's-land somewhere between 'occupation of an entire field' and 'speaking directly' to some particular feature of the maritime tort." 253 In short, a court should not attempt to shoehorn a mangled version of maritime law into a statute designed to replace a "fragmented collection of Federal and State laws' with a 'single Federal law providing cleanup authority, penalties, and liability for oil pollution." 254

When the incompatible maritime track is set aside and OPA's liability provisions are read correctly, plaintiffs are able to recover the economic losses suffered because of the Moratorium. After advancing a proximate causation standard, the court candidly states, "[t]here can be no doubt that the Government would not have imposed the Moratorium had the HORIZON/Macondo blowout and oil spill not occurred." ${ }^{255}$ In effect, it admits causation. However, it then incorrectly parses the words of the Moratorium and emphasizes the Secretary's concern for the "possible future blowouts and oil spills from wells other than Macondo." 256 It states that "the perceived threats of discharge from other wells are different OPA 'incidents' (if these are OPA incidents at all) than the HORIZON/Macondo incident for which BP is a responsible party." ${ }^{257}$ When analyzing the Moratorium, the court uses the incorrect two-step proximate causation standard, thereby

251. John J. Costonis, The BP Bundle Ruling: Federal Statutory Displacement of General Maritime Law (Part II), 44 ENVTL. L. REP. NEWS \& ANALYSIS 10108, 10108-09 (2014).

252. Id. at $10109-12$.

253. Id. at 10112.

254. See Costonis, supra note 251, at 10027.

255. In re "Deepwater Horizon", 168 F. Supp. 3d 908, 916 (E.D. La. 2016). Note that the court avoids using the language originally used by Secretary Salazar "as a result of the Deepwater Horizon explosion and spill ..." Secretary Salazar highlights the statutory language, "result of," as well as the incident, "explosion," and the result "spill." Without further parsing of the moratorium language, such a construction satisfies the statutory requirements. Id. at 910.

256. Id. at 916 .

257. Id. By reading the perceived threats as separate incidents, the court is essentially reading in the superseding and intervening causes for which BP argued. 
denying the Moratoria plaintiffs their recovery. It incorrectly uses the "result from" language to find that the Moratorium did not result from the incident, and following this conclusion, brushes aside the plaintiff's valid claims. In direct contradiction of its own definition of liability, namely that there must be damage to natural resources, it states:

In OPA terms, then - and putting aside the question of whether 'plaintiffs' claims are due to the injury, destruction, or loss of property or natural resources - the OPA Test Case Plaintiffs' losses did not result from the discharge or substantial threat of discharge of oil from the Macondo Well: the resulted from the perceived threat (whether substantial or not) of discharge from other wells. ${ }^{258}$

Once again, the liability provisions of OPA contemplate damages that "result from such incident," ${ }^{259}$ where "incident" is defined as "any occurrence or series of occurrences having the same origin, involving one or more vessels, facilities, or any combination thereof, resulting in the discharge or substantial threat of discharge of oil." ${ }^{260}$ The incident is not defined by the discharge; the discharge is defined by the incident. The incident is the series of occurrences leading up to the discharge or threat of discharge - the actual punishable actions of the responsible party. ${ }^{261}$ To read it as the former would once again create a narrow loophole for possible responsible parties to avoid liability for wrongful actions were the discharge to precede the event. ${ }^{262}$ The incident in the immediate case is the blowout, explosion, subsequent fire, and sinking of the Deepwater Horizon, which most certainly resulted in the discharge of oil. The Moratorium was issued as a result of this incident, and the court itself concedes this. ${ }^{263}$ Regardless of whether or not the Secretary enumerated other reasons for the Moratorium (namely that there were not enough response vessels in case of another spill and there was general concern for the safety practices of the industry ${ }^{264}$ ), the fact remains that the Moratorium resulted from the incident, i.e. the blowout, explosion, subsequent fire and sinking of Deepwater

258. Id. If read together, it seems the court only intends for the true definition of "incident" to be considered in the first step of its analysis. It then changes the definition to mean only the discharge in the second step, precluding recovery by the Plaintiffs. It has written itself in circles, creating an unintelligible liability standard.

259. 33 U.S.C. $\$ 2702$ (a) (2012).

260. 33 U.S.C. $\$ 2701(14)$ (2012).

261. Id.

262. See discussion supra p. 49.

263. In re "Deepwater Horizon”, 168 F. Supp. 3d 908, 911 (E.D. La. 2016).

264. Id. at 916 . 
Horizon. ${ }^{265}$ All of the Secretary's enumerated reasons for the Moratorium originate from the blowout.

The Coast Guard declared the Deepwater Horizon disaster a "Spill of National Significance" under the National Contingency Plan, the first in U.S. history. ${ }^{266}$ Such a spill may be declared when it is "so complex that it requires extraordinary coordination of federal, state, local, and responsible party resources to contain and clean up the discharge." 267 It is no wonder then that the Secretary had concerns about the number of response vessels necessary to attend to the Deepwater Horizon, leaving serious gaps in the resources available to respond to other spills. But it is clear that the response vessels were all deployed as a result of the incident. The declaration of the Spill of National Significance requiring an unprecedented amount of response resources and the resulting concern that there were not enough resources to address another spill in the Gulf were results of the incident. Further still, the "perceived weakness of industry-wide safety measures," is a result of the incident. In sum, and in the words of Judge Barbier, "[t]here can be no doubt that the Government would not have imposed the Moratorium [with all of its enumerated factors] had the HORIZON/Macondo blowout and oil spill not occurred." 269

BP proffered a number of dubious arguments as to why the Moratorium was not a result of the Deepwater Horizon incident. ${ }^{270}$ However, given the lengthy analysis provided by this article, it is clear that none of them are viable under OPA. Despite this, the court, without any plausible statutory explanation, ${ }^{271}$ accepted many of them as true and dismissed the economic claims of many deserving plaintiffs. Generally, BP's ultimate argument was that there was some sort of blanket Moratorium defense. ${ }^{272}$ Such a defense directly contravenes the agreement by all parties involved that this issue, and OPA causation in general, is a fact-intensive inquiry. ${ }^{273}$ To prove its blanket defense, BP argued that there was some sort of shift of responsibility

265. Id.

266. Id. at 909-10.

267. Id. at 909 n.1 (citing 40 C.F.R. $\$ 300.5$ (2016)).

268. Id. at 916 .

269. Id. (alteration to original).

270. Id. at 914 .

271. See discussion supra Section II, III, IV (arguing that the court improperly interpreted OPA's liability provision).

272. In re "Deepwater Horizon", 168 F. Supp. 3d at 914.

273. In re "Deepwater Horizon”, 808 F. Supp. 2d 943, 965-66 (E.D. La. 2011). 
to a third party i.e. the United States government, or that this was a superseding cause, which is generally reserved for proximate causation arguments. ${ }^{274}$ The Plaintiffs highlight the impropriety of considering third party decisions in assessing causation:

Yet, taking BP's current arguments to their logical conclusion, none of these [economic damage] plaintiffs would arguably be entitled to recover: The Government makes deliberate decisions about which areas are closed to commercial fishermen; tourists and other travelers ultimately decide whether they will make or cancel travel plans; hotel operators decide whether they will lay off employees, cut hours, or reduce wages; the Coast Guard makes deliberate decisions about whether to suspend navigation on a river; and different potential purchasers are motivated by numerous considerations when they decide whether, where, and at what price to buy or lease property, frequent restaurants, or obtain new furniture. ${ }^{275}$

The suggested shift precludes all factual inquiry into the fault of BP. As noted above, the government negligence exception found in the CWA was not included in OPA and therefore cannot be invoked here. In addition, the very strict defenses to liability require that fault be placed entirely on a third party: an act of God or a war. ${ }^{276}$ None of these defenses could be, let alone actually were, proved by BP.

One manifestation of the blanket Moratorium defense was BP's argument that the "Moratorium was not an unavoidable mandatory response to the oil spill, but instead newly crafted measures designed to facilitate an industry-wide review of drilling practices and, therefore, discretionary acts aimed at avoiding future spills." ${ }^{277}$ As previously noted, the Moratorium and its enumerated reasons for existence were all a result of the incident. Further still, nowhere in the statute does it state that the response actions of the government must be "unavoidable" or "mandatory." BP is once again grafting requirements into the statute beyond what Congress intended. In fact, the Moratorium fits well within the definition of "remove" or "removal" found in $\S 2701(30)$. As discussed previously, under $\S 2701(30)$, "remove" or "removal" includes not only the physical containment and removal of oil, but also the "taking of other actions as may be necessary

274. “Deepwater Horizon” 168 F. Supp. 3d at 914.

275. Opposition to BP's Renewed Motion to Dismiss the So-Called "Moratoria" and "Permitoria” Claims, "Deepwater Horizon”, 168 F. Supp. 3d 908 (E.D. La. 2016) (“"No. 10MD02179)

276. 42 U.S.C. $\$ 9607$ (b) (2012).

277. In re "Deepwater Horizon", 168 F. Supp. 3d at 914. 
to minimize or mitigate damage to public health or welfare."278 Therefore, the Moratorium falls under the definition of "remove" or" removal," for it was a step taken to minimize or mitigate damage to public health or welfare, namely through prevention of another spill and addressing industry wide safety issues brought to light by the Deepwater Horizon blowout and oil spill.

Ignoring the fact that the Moratorium fits within the definition of "removal" under OPA, the court also distinguishes it from the "shutdown cases," cited by the Plaintiffs, specifically (and only) Dunham-Price. As discussed above, Dunham-Price and the rest of the shutdown cases are analogous to the Moratorium situation. ${ }^{279}$ These shutdowns were the result of cleanup efforts, which include removal measures. The court states, with no explanation, that "[s]ignificantly, and unlike the Moratorium, the river closure was part of the effort to contain and clean up the spill from defendant's facility." ${ }^{280}$ It is not clear how the Moratorium is significantly unlike "part of [an] effort to contain and clean up" the BP oil gushing into the Gulf at an alarming rate. The Moratorium itself notes that there were a record number of resources deployed to aid in this regard, which was part of the impetus for its issuance. ${ }^{281}$ Moreover, the Moratorium, as an action considered necessary to minimize or mitigate damage to the public health or welfare, fits within the definition of "remove" or "removal." DunhamPrice emphasized the fact that the Calcasieu River, the closed body of water of concern, met OPA's definition of a natural resource, and its closure warrants the plaintiff's claims. ${ }^{282}$

Furthermore, $A C L$ notes that the Fifth Circuit has found triable issues of fact where "claimants seek damages for loss of business resulting from the closure or loss of use of a natural resource such as a river." 283 Thus, it is the closure of the resource, not the oiling, that courts consider significant; the incident rather than the discharge or threat of discharge is the key component of closure analysis. It is analogous to the claims of a fisherman: when he claims economic

278. 33 U.S.C. § 2701(30) (2012) (emphasis added).

279. Dunham-Price Grp., LLC v. Citgo Petroleum Corp., No. 2:07-CV-1019, 2010 WL 1285446, at *2 (W.D. La. Mar. 31, 2010).

280. "Deepwater Horizon", 168 F. Supp. 3d at 916.

281. Id.

282. Dunham-Price Grp. v. Citgo Petroleum Corp, 2010 WL 1285446, at*3 (W.D. La. 2010).

283. United States v. Am. Commercial Lines, LLC, No. 11-CV-2076, 2016 WL 4987208, at*5 (E.D. La. Sept. 19, 2016). ACL attempted to argue that economic damages resulting from the closure, rather than the direct oiling, were not compensable under OPA. The court clearly disagreed. 
damage, it is not for the loss of oiled fish, but rather, his inability to access the fish. ${ }^{284}$ Likewise, the Moratorium, has impeded the plaintiff companies from reaching or pursuing their business. In fact, even Professor Goldberg observed that "if a spill were to deprive commercial fishermen of expected profits by killing fish they ordinarily would catch and sell, or by causing authorities to bar the fishermen from accessing those fish for a period of time, the fishermen would be entitled to recover." ${ }^{285}$ The Moratorium claims, like those of the fishermen, are far from remote. These plaintiffs were barred from accessing their trade as a result of the Deepwater Horizon disaster. ${ }^{286}$ The Moratorium is clearly a response to the spill, and resulted in the closure of a natural resource identically, save for its much larger scale, to the "shutdown cases."

The court highlights the fact that the Plaintiffs "assert that the Government has imposed drilling moratoria every year from 1982 through 2008, yet Plaintiffs cite no cases in which a private party has been held liable (under OPA or other law) for losses caused by a Moratorium." ${ }^{287}$ It concludes that the absence of such cases indicates that the plaintiffs' claims are not recoverable. ${ }^{288}$ Putting aside the fact that this logic flies in the face of our justice system, this Moratorium, like the oil spill it resulted from, is unique. Generally, moratoria are implemented for political, economic, and scientific reasons, often with international relations considerations. ${ }^{289}$ The moratoria cited by the plaintiffs address political motives, but some did indeed follow oil spills. ${ }^{290}$ However, the court incorrectly characterizes the lawsuits that followed. Because many of the spills cited by the plaintiffs pre-date OPA, a moratorium would not have been a triable issue. ${ }^{291}$ For those that came after OPA's 1990 passage, at least two of the cited cases settled out of court, but not before finding that shutdown claims were triable under OPA's liability standard. ${ }^{292}$ However, unlike these

284. See "Deepwater Horizon", 168 F. Supp. 3d at 918, n.11.

285. Robertson, supra note 41, at 164 (quoting Goldberg, supra note 72).

286. “Deepwater Horizon”, 168 F. Supp. 3d at 912 (quoting Blake Complaint para. 60, No.131185, Rec. Doc. 1).

287. Id. at 917 .

288. Id.

289. See generally Curry L. Hagerty, Cong. Research Serv., R41133, Outer CONTINENTAL SHELF MORATORIA On OIL AND GAS DEVElOPMENT (2011).

290. Opposition to BP's Renewed Motion to Dismiss the So-Called "Moratoria" and "Permitoria" Claims at 11-12, In re "Deepwater Horizon", 168 F.Supp.3d 908 (E.D. La. 2016) (No. 10MD02179).

291. Id.

292. Id.; see In re Settoon Towing, No. 07-1263, 2009 WL 4730969, at *4 (E.D. La. Dec. 4, 
relatively small spills and closures, the BP Disaster and subsequent Moratorium is unprecedented in its size and scope ${ }^{293}$ Furthermore, as noted by the Secretary himself, this unique Moratorium was the direct result of the Deepwater Horizon blowout.

The argument that the Moratorium would have happened regardless of whether or not a spill occurred does not negate the fact that it resulted from the Deepwater Horizon blowout. This situation is analogous to the situation in Hyundai, where Hyundai argued that Coast Guard salaries do not fall under response and removal costs because they would have been paid regardless of whether or not they were responding to an OPA incident. ${ }^{294}$ As discussed above, the court correctly held that such salaries did result from the incident, noting "[t]he fact that, if this near-disaster had not occurred, the personnel would have been paid to perform some other task does not alter the reality that the mishap did occur and the Coast Guard personnel were paid to monitor a potential spill." ${ }^{295}$ Likewise, the fact that a moratorium would likely have occurred for different reasons does not change the fact that this specific Moratorium was a result of the incident; as such, the plaintiffs are entitled to their economic damages.

The fact that "the Coast Guard, as part of its administration of the Oil Spill Liability Trust Fund, has denied claims that are 'a direct result of the moratorium, not a direct result of an oil discharge" ${ }^{296}$ has little bearing on whether or not the Moratorium resulted from the incident. ${ }^{297}$ In fact, the Coast Guard, as noted above, has a tendency to interpret regulations in its favor and in such a way that hinders industry, regardless of whether or not industry claims are valid and compensable. ${ }^{298}$ Unfortunately, it appears that the court is perpetuating the prejudice against the oil industry evidenced in

2009); Dunham-Price Grp. v. Citgo Petroleum Corp., No. 2:07-CV-1019, 2010 WL 1285446, at *3 (W.D. La. Mar. 31, 2010).

293. "Deepwater Horizon", 168 F. Supp. 3d at 909-10.

294. United States v. Hyundai Merchant Marine Co., 172 F.3d 1187, 1192 (9th Cir. 1999).

295. Id.

296. In re "Deepwater Horizon", 168 F. Supp. 3d at 918.

297. In Nguyen v. American Commercial Lines, Inc., Nos. 11-1799, 11-2705, 2014 WL 3587490 , at *1 (E.D. La. July 18, 2014), Judge Lemelle correctly notes "it is clear that 33 C.F.R. $\$ 136.105$ [The Coast Guard regulation regarding presentment] is inapplicable to claims to responsible parties because the Coast Guard lacks any rule-making authority concerning claims to entities other than the [Oil Spill Trust Fund"]," meaning the Coast Guard has not been delegated any binding, rule-making authority. $I d$. at $* 5$ (emphasis added). As such, decisions it makes regarding the Fund cannot be used as legal precedent. Id.

298. See Holmen, supra note 177, at 1909. 
Conoco, Hyundai, and Gatlin. ${ }^{299}$ It makes very little sense and in fact directly disregards the purpose of statutory authority to read a statute differently based solely on who is bringing a claim.

\section{CONCLUSION}

OPA is an important law that very plainly sought to alter the dynamics of any post-oil spill litigation. Indeed, its clear language was designed to induce potentially responsible parties to adhere to heighted standards of care to avoid spills. In the future, courts should aim to adhere to statutory cannon: "[i]n construing a statute, the court is 'guided not by a single sentence or member of a sentence, but [must] look to the provisions of the whole law, and to its object and policy."'300 The Oil Pollution Act's obvious policy, as iterated by numerous House and Senate reports, was to ensure that all those adversely affected by a catastrophic oil spill could recover. Its causation standard, as evidenced by its "result from" and "due to" language and illuminating "incident" definition, is not the two-step proximate causation standard championed by the court, but rather a nexus standard that fulfills Congress' intention to expand recovery beyond Robins and $M / V$ TESTBANK. OPA was and remains driven by strong public policy. True public policy treats all claimants as equal. Inequitable application of OPA as is seen in Gatlin and the Moratorium claims flies in the face of such public policy and should not stand as precedent.

This ruling is not simply about the Moratorium; it is about setting dangerous precedent in the Fifth Circuit that has the ability to create loopholes for responsible parties, narrow the recovery gap, and reinstate the Robins and $M / V$ TESTBANK rule that Congress sought to supersede in enacting OPA. On August 10, 2016, the parties to the Moratorium case stipulated to the dismissal of the Plaintiff's appeal. ${ }^{301}$ As such, the court's narrow interpretation of OPA and inadvertent inclusion of a two-step proximate causation standard is now precedent. The Fifth Circuit, situated in offshore oil country, is arguably faced with more significant OPA claims than much of the country. Precedent that reads the statute narrowly and inadvertently creates loopholes will only serve to harm an already economically disadvantaged region that suffers repeatedly from industry accidents.

299. Id.

300. Dole v. United Steelworkers, 494 U.S. 26, 35 (1990).

301. Stipulated Agreement for Dismissal of Appeal, In re "Deepwater Horizon", 168 F. Supp. 3d 908 (E.D. La. 2016) (No. 513630893), appeal dismissed, No. 16-30245 (5th Cir. Aug. 10, 2016). 